\title{
Civil Rights in International Law: Compliance with Aspects of the "International Bill of Rights"
}

\section{Citation}

Simmons, Beth. 2009. Civil rights in international law: Compliance with aspects of the "International Bill of Rights." Indiana Journal of Global Legal Studies 16(2): 437-481.

\section{Published Version}

http://dx.doi.org/10.2979/GLS.2009.16.2.437

\section{Permanent link}

http://nrs.harvard.edu/urn-3:HUL.InstRepos:3017500

\section{Terms of Use}

This article was downloaded from Harvard University's DASH repository, and is made available under the terms and conditions applicable to Open Access Policy Articles, as set forth at http:// nrs.harvard.edu/urn-3:HUL.InstRepos:dash.current.terms-of-use\#OAP

\section{Share Your Story}

The Harvard community has made this article openly available.

Please share how this access benefits you. Submit a story.

\section{Accessibility}




\title{
Civil Rights in International Law: Compliance with Aspects of the 'International Bill of Rights'
}

\author{
Beth Simmons \\ Department of Government \\ Weatherhead Center for International Affairs \\ Harvard University \\ bsimmons@wcfia.harvard.edu
}

Prepared for the Workshop on Global Constitutionalism: Process and Substance

Thursday 17th January - Sunday 20th January 2008, Kandersteg, Switzerland

\begin{abstract}
:
International law has developed what many might consider a constitutional understanding of individual civil rights that individuals can claim vis-a-vis their own governments. This paper discusses the development of aspects of international law relating to civil rights, and argues that if this body of law is meaningful we should see evidence of links between acceptance of international legal obligation and domestic practices. Recognizing that external forms of enforcement of civil rights is unlikely (because not generally in the interest of potential "enforcers"), I argue that international civil rights treaties will have their greatest effect where stakeholders - local citizens - have the motive and the means to demand treaty compliance. This is most likely to be the case not in stable autocracies, where such demands are likely to be crushed, nor in stable democracies, where the motive to mobilize is attenuated due to rights saturation, but in transitional countries where the expected value of mobilization is maximized. Thus, I test the hypothesis that the International Covenant on Civil and Political Rights is likely to have its greatest positive effects in transitional countries - those that have had some fleeting experience with democratic governance. This proposition is tested quantitatively with indicators for freedom of religious practice, fair trials and the death penalty. The proposition is weakly supported by extremely stringent statistical models that control for the endogeneity of the treaty commitments, country and year fixed effects, and other obvious influences on civil rights practices. I conclude that the International Bill of Rights has the power to influence the direction of rights practices in fluid political situations, but cannot magically transform autocracies into liberal guarantors of civil liberties. Still, these effects are important, and the most we can expect from scraps of paper which the international community has been reluctant to enforce.
\end{abstract}




\section{Civil Rights in International Law: Compliance with Aspects of the 'International Bill of Rights'}

Scholars, international lawyers and activists have grown accustomed to the claim that an identifiable set of international instruments constitute "The International Bill of Rights." ${ }^{\text {The }}$ Universal Declaration for Human Rights (UDHR) ${ }^{2}$ along with two binding treaties, the International Covenant for Civil and Politic Rights (ICCPR) ${ }^{3}$ and the International Covenant for Economic, Social and Cultural Rights (ICESCR) ${ }^{4}$ have come to be thought of as international society's clearest expression of a core set of human rights commitments with "constitutional” status in international law. The purpose of this paper is not to contest the claim of these agreements' constitutionalism. Rather it is to ask whether the promulgation of the rights contained in these agreements over past five decades has contributed to their realization. Empirically, what has the "International Bill of Rights" contributed to the realization of these rights around the world?

The emphasis of this paper is empirical, but it is based on several theoretical claims. First, the ratification of human rights agreements can stimulate domestic demands for their realization that certain governments might find costly to recognize or to cope with. Groups begin to form to demand their rights once these are formally acknowledged by governments through ratification, though the incentives to mobilize will differ predictably across different kinds of political regimes. Furthermore, the greater groups' ability to monitor the government, the greater will be the pressures to comply with international legal obligations protecting civil rights. There is some evidence that the "International Bill of Rights" has contributed to an improvement in certain civil rights practices, around the world, largely because of the public commitment ratification requires. Ratification stimulates demands for compliance, making it harder than it would otherwise be for a government to ignore international civil rights norms.

The paper is organized as follows. The first section provides some background and discusses the place of civil rights in international law. The second section provides some

\footnotetext{
1 Among many sources, see Henkin 1981.

2 Universal Declaration of Human Rights, Adopted and proclaimed by General Assembly resolution 217 A (III) of 10 December 1948. Text at http://www.un.org/Overview/rights.html.

3 International Covenant on Civil and Political Rights, G.A. res. 2200A (XXI), 21 U.N. GAOR Supp. (No. 16) at 52, U.N. Doc. A/6316 (1966), 999 U.N.T.S. 171, entered into force Mar. 23, 1976. Text can be found at http://www1.umn.edu/humanrts/instree/b3ccpr.htm.

4 International Covenant on Economic, Social andCultural Rights. Adopted and opened for signature, ratification and accession by General Assembly resolution 2200A (XXI) of 16 December 1966, entry into force 3 January 1976. Text at http://www.unhchr.ch/html/menu3/b/a_cescr.htm.
} 
theoretical justification for expecting treaties to influence civil rights and potentially other human rights practices. The remaining sections are empirical and test the proposition that treaty ratification - focusing on the ICCPR and its optional protocol relating to the death penalty - have had a significant "commitment effect." The pattern of evidence supports the idea that this effect is conditional. It is strongest where domestic groups have both the motive and the means to make civil rights demands of their government. Furthermore, it is strongest in cases in which the right in question is centrally violated and relative easy to detect and monitor. I compare the evidence across three civil rights areas: freedom of religion, fair trials, and the death penalty. The key finding is that international legal obligations make an important and positive difference to practices in these three areas, but the greatest differences are to be found where citizens have the capacity and motivation to mobilize and for rights that are most easily observed and monitored.

\section{Background: Civil Rights and International Law}

Civil and political rights were one of the first areas to be addressed by the international human rights treaty regime that was negotiated in the mid-1940s. Along with economic and social rights, they were the central core - the first 19 articles - of the Universal Declaration of Human Rights, passed unanimously by the General Assembly in 1948. But for reasons that have been discussed elsewhere ${ }^{5}$ - foot dragging, notably by the major powers - it took 18 years to agree upon a binding treaty covering civil and political rights, and to then negotiate its contents (despite the fact that most of its provisions were already contained in the Universal Declaration itself). ${ }^{6}$ At the insistence of the United States, a move was made to bifurcate the social and economic rights on the one hand from the civil and political on the other. The ICESCR contains the codification in treaty form of the former, while the latter are encoded in the ICCPR. The ICCPR, along with the ICESCR and the Universal Declaration, are often referred to collectively (if loosely) as the "International Bill of Rights."7

The ICCPR is the primary global treaty devoted to what people have come to call "first generation" human rights. ${ }^{8}$ These are the complex of "Enlightenment rights" that in their day were crucial in overthrowing feudalism and shattering the uncontested divine right of kings. ${ }^{9}$

\footnotetext{
5 Simmons forthcoming: ch. 2.

6 See Articles 3-21 of the UDHR. Many scholars also hold that at least some of the obligations found in the ICCPR reflect customary international law. See Henkin 1995.

7 Ibid.

8 The delineation of civil and political rights as "first generation human rights" has become standard terminology. See for example, Encyclopædia Britannica 2007; Ishay 2004: 3.

9 Ishay 2004: 7.
} 
Infused with Enlightenment notions of individualism and laissez-faire, this first generation of rights with their focus on the rights of the individual vis-à-vis political authority has come largely to be thought of as a set of "negative rights," or rights that require government to abstain from denigrating (rather than requiring governments to intervene on behalf of) human dignity.

In large part, the emphasis on “negative freedoms” can be seen in the ICCPR's Part III, which contains the treaty's substantive obligations. ${ }^{10}$ Individuals have a right to their lives (Article 6), to be free from torture or degrading treatment (Article 7), from slavery or servitude (Article 8), a right to liberty and security of person (Article 9), the right to free movement (Article 12), to a fair trial (Article 14), freedom of religion and thought (Articles 18 and 19), peaceful assembly and free association (Articles 21 and 22). Rights of political participation are guaranteed in Article 25. Equality before the law and minority rights are protected in Articles 26 and 27. But the treaty suggests positive rights of individuals as well. "Each state Party to the present convention,” according to Article 2(1), “undertakes to respect and to ensure to all individuals within its territory and subject to its jurisdiction the rights recognized in the present convention, without distinctions of any kind...” The treaty thus contains an affirmative obligation of states to organize civil and political life in ways that make the enjoyment of the rights contained in the treaty possible.

The drafters of the treaty did not, however, envisage that these rights would be absolute; both the $\mathrm{ICCPR}^{11}$ and the Universal Declaration ${ }^{12}$ recognize that these rights may need to be limited when necessary to protect certain public interests. ${ }^{13}$ Many states reinforce and specify their rights of derogation through the use of reservations. ${ }^{14}$ Some - China with respect to freedom of religion is an outstanding example - provide for the civil freedoms contained in the ICCPR in their domestic law, but then take back the guarantee with domestic derogations that are much broader than the ICCPR itself allows. ${ }^{15}$ Many civil rights - citizens' rights vis-à-vis the state - raise culturally sensitive controversies about the proper relationships between the

\footnotetext{
10 The text of the ICCPR can be accessed at http://www1.umn.edu/humanrts/instree/b3ccpr.htm (accessed 15 July 2003).

11 ICCPR, Article 4.

12 UDHR, Article 29(2).

13 In 1985, The Economic and Social Council negotiated a set of principles defining the conditions onder which derogation of ICCPR treaty obligations are in fact allowed. See United Nations, Economic and Social Council, Siracusa Principles on the Limitation and Derogation Provisions in the International Covenant on Civil and Political Rights, U.N. Doc. E/CN.4/1985/4, Annex (1985); http://www1.umn.edu/humanrts/instree/siracusaprinciples.html.

14 The North African countries tend to make "states of emergency claims" for purposes of derogation; see Allain and O'Shea 2002: 90.

15 Kolodner 1994: 484.
} 
individual, society, and the state. ${ }^{16}$ Ideological differences drove East and West to spar over civil rights during the Cold War. Today, civil rights are among those most likely to be dismissed as "western."

In order to facilitate enforcement of these obligations, the ICCPR established the Human Rights Committee (Article 28), ${ }^{17}$ whose main purpose is to enhance the mechanisms of accountability through its authority to monitor and receive state reports that are due on a regular basis. The Human Rights Committee is also empowered by the convention to consider complaints of one state against another (Article 41), although this process has never been used. The Committee is also empowered, through the first Optional Protocol, to consider individual complaints against one's own government. ${ }^{18}$ Although the Human Rights Committee was established expressly as a committee of experts rather than a court, analysis of its recent practice reveals that it is becoming increasingly "court-like." 19

The ICCPR is not the only treaty to have addressed civil and political rights, but it is certainly the most central. Many of these rights have also been developed at the regional level, and in Europe with accompanying institutions with real enforcement power. The first 18 Articles of the European Convention for the Protection of Human Rights and Fundamental Freedoms (1953) anticipates the civil and political rights covered by the ICCPR, and Section II establishes a regional court to assure enforcement. ${ }^{20}$ All of the first generation civil rights covered in the ICCPR are also detailed in the American Convention on Human Rights, book-ended by guarantees of juridical personhood and judicial protection of the rights contained in the treaty. ${ }^{21}$ The African Charter on Human and Peoples’ Rights (1981) contains in a more limited and contingent form some of the civil rights found in the ICCPR, including liberty and security of person, a right to a trial, freedom of conscience, free practice of religion, the right to disseminate

\footnotetext{
16 The "Asian values" debate is pertinent in this regard. On the idea that the global civil rights regime may not be compatible with Southeast Asian notions of statehood see Mohamad 2002.

17 Forsythe, for example prefers to think of the activities of the Human Rights Committee as "socialization" rather than enforcement Forsythe 1985.

18 For a legal analysis of the individual right of petition before the Human Rights Committee see De Zayas, Moller, and Opsahl 1985; Ghandhi 1986; Heffernan 1997; McGoldrick 1991; Myullerson 1992. For an example of a Human Rights Committee communication process that had an impact on government practices in the case of New Zealand see De Zayas, Moller, and Opsahl 1985.

19 Helfer and Slaughter 1997. For a review of the literature on the effectiveness of the Human Rights Committee, see Donnelly 1998; Keith 1999.

${ }^{20}$ Convention for the Protection of Human Rights and Fundamental Freedoms, 213 U.N.T.S. 222, entered into force Sept. 3, 1953.

${ }^{21}$ American Convention on Human Rights, O.A.S. Treaty Series No. 36, 1144 U.N.T.S. 123, entered into force July 18, 1978. See the extensive list in Chapter II (Articles 3-25).
} 
one's opinion, and free assembly and association. ${ }^{22}$ Practically the entire panoply of civil rights has been exported from the ICCPR to other international conventions aimed at protecting specific groups, including the Convention on the Elimination of all Forms of Racial Discrimination ${ }^{23}$ and the Convention on the Rights of the Child. ${ }^{24}$

\section{Theoretical Argument: Compliance with the ICCPR}

Why should governments comply with the treaties they ratify? The current state of the literature suggests that, especially in the human rights area, they largely do not. Human rights treaties are not likely to be enforced, according to a dominant view, and for this reason states are likely to ratify to enjoy the expressive benefits of doing so without concern that their legal commitment will be enforced.

The cynical view flows from an emphasis on international enforcement, but a neglect of domestic politics. While it may be true that international actors - and especially other states have little incentive to enforce their peer's human rights commitments in any serious and systematic ways, domestic actors have a clear stake in their enforcement. For the locals, their rights and freedoms are at stake. Thus we should expect that if international law with respect to human rights is to be enforced, the most consistent pressure to do so should emanate from domestic politics. ${ }^{25}$

There are a number of ways in which international human and civil rights treaties might be expected to influence domestic politics. Most obviously, most treaties are exogenous to the domestic legislative activities of most states. The question of their ratification and implementation places an issue on the national agenda that might not have been there in the absence of the treaty adoption itself. Even if they are not especially controversial, the existence of a treaty raises the question of ratification, putting an item on the national legislative agenda that might not have been there otherwise. Treaties can therefore have policy effects without raising much controversy, largely through elite consensus in favor of ratification.

\footnotetext{
22 African [Banjul] Charter on Human and Peoples' Rights, adopted June 27, 1981, OAU Doc. CAB/LEG/67/3 rev. 5, 21 I.L.M. 58 (1982), entered into force Oct. 21, 1986: See generally articles 6-14. ${ }^{23}$ International Convention on the Elimination of All Forms of Racial Discrimination, G.A. res. 2106 (XX), Annex, 20 U.N. GAOR Supp. (No. 14) at 47, U.N. Doc. A/6014 (1966), 660 U.N.T.S. 195, entered into force Jan. 4, 1969. See especially Article 5 (a-d).

24 Among other things, guaranteeing children a right to religious freedom and free conscience, peaceable assembly, and civil rights when accused of crimes (CRC, articles 14, 15 and 40 respectively).

25 Simmons forthcoming: ch. 3 .
} 
The more interesting cases, however, are those in which governments ratify an international human rights agreement yet make no move to implement or to comply with it. Why should a ratified treaty make any difference in such cases? One reason is that treaties constitute law in many countries, and could strengthen civil rights litigation. Of course, for this mechanism to work, it is necessary that the courts in the country in question are sufficiently independent of the political powers that they can render an independent judgment with some probability of constraining political actors. Litigation in national courts is one of the best strategies available for creating home-grown pro-rights jurisprudence. ${ }^{26}$ Of course, the availability of treaty law certainly does not assure litigation will take place. Potential litigants must be aware - or come to be made aware - of their rights under international law (or under the implementing legislation it has inspired). A certain degree of "legal literacy" is required if individuals are to access the courts. ${ }^{27}$ Litigation is limited for a number of reasons, ${ }^{28}$ but cases involving international legal guarantees touching on civil rights seem to be on the rise in many places. ${ }^{29}$

Quite aside from litigation (or sometimes using it as part of a broader strategy), international legal agreements can be important aspects of domestic political mobilization to demand rights adherence from governments. Suppose that the probability that citizens will mobilize to demand a civil right depends on two factors: the value they place on that right and the likelihood that mobilization will be effective. These two factors represent the "expected value"

\footnotetext{
${ }^{26}$ Osofsky 1997. On transnational public law litigation generally, see Koh 1991.

27 On this point see the work of Merry 2006.

28 Frymer 2003. pp. 486-488. On the potential for human rights litigation in the United States, see Tolley 1991. The point being that the potential exists, but it is relatively limited. Individuals' access to courts varies greatly. The Supreme Court of India, for example has decided that cases can be taken upon behalf of those in poverty who are unable to file for themselves, and that such cases can be initiated simply by letter. See Ellmann 1998. p. 358.

${ }_{29}$ Examples of litigation involving rights guaranteed by ratified treaties can be found in every region of the globe. Human rights litigation is burgeoning in some parts of the developing world, notably in Latin American countries with fairly recent histories of severe rights abuses. See Kim and Sikkink 2007. Several African countries have used international treaties to shape their own jurisprudence on civil and political rights. Namibian courts have referred to the ICCPR to provide guidance in the determination of national discrimination law. Tshosa 2001: 110. Botswanian courts have made reference to international instruments to determine reasonable criteria for a fair trial. Tshosa 2001: 172. The Russian Court has used international law to support its decisions in criminal justice cases as well, instructing the rest of the judiciary to apply the ICCPR over domestic legislation in cases involving petitions about the lawfulness of detentions. Danilenko and Burnham 2000. p. 43. In Japan women have used the courts to realize their right not to be discriminated against in employment, while in Israel, the Supreme Court has ruled that certain interrogation practices do, in fact, constitute torture as understood by the Committee Against Torture. These and other examples of successful litigation based on human rights treaties are collected by a variety of NGOs. See for example http://madre.org/articles/int/hrconv.html] Cases filed in the Indian Supreme Court in 1994 "asked the Court to order the government to show what steps were being taken to end discrimination in the personal laws consistent with the principles of CEDAW" thus effectively forcing the government to articulate the extent of its compliance with its 1993 ratification commitment. Merry 2006: 167.
} 
of mobilization. The expected value of mobilization varies across countries. In general, the value a citizen is likely to place on a treaty-protected civil right will be higher in non-democratic countries where the marginal value of an additional right is likely to be much higher than in a democracy, where access to a large number of rights is already secure. But at the same time, the likelihood that mobilization will succeed is higher in a democracy, where more responsive government is the norm. When we combine these two factors, as illustrated in Figure 1a, it becomes clear that the expected value of mobilization is rather small in both stable democracies and stable autocracies, but significant in countries in the middle - that have some possibility of non-autocratic governance yet do not have a broad and secure panoply of civil rights. In these countries, citizens have both the motive and the means to organize to demand respect for civil rights from their governments.

\section{[FIGURE 1A ABOUT HERE]}

Ratification of the “International Bill of Rights” influences citizens’ mobilization calculations in two ways. On the one hand, in non-democracies, ratification injects a new model of rights into the domestic discourse, potentially altering expectations of domestic groups, and encouraging them to imagine themselves as entitled to forms of official respect they may never have dreamt themselves entitled to. The model has all the more power, because the government has actively assented to the rights in question, imbuing them with a legitimacy they would not have in the absence of ratification. As constructivist theory suggests, there are good reasons to attribute an educative function to international legal instruments, especially once they have been formally accepted by government authorities. This educative function of international treaties ought to be weak or even absent in democracies, where many if not most of the civil rights in question are already part of political life.

On the other hand, international treaties are much more likely to enhance the probability of success in making civil rights demands in a democracy than in a non-democracy. Democratic governments are much more constrained by constitutional and statutory law; they are more likely to have independent courts, and to be composed of a citizenry that is quite legally literate. A ratified treaty will therefore have strategic legal value in a democracy that it is likely to lack in an autocracy. Citizens that are armed with "new law" are more likely to be more empowered in a system based on the rule of law than one based on more arbitrary and unconstrained political authority. 


\section{[FIGURE 1B ABOUT HERE]}

Thinking of these factors in combination leads to the central expectation of this paper: Where we are likely to see the most significant treaty effects - at least with respect to civil and political rights - is in the less stable, transitioning "middle ground” regimes. In these countries, individuals have both the motive and the means realistically to press their governments to take international human rights treaties seriously. Treaties can still play a legitimating function, reassuring a nascent coalition that their demands are legitimate and solidifying their identity as individuals with a moral and legal case to make vis-à-vis their government. Mobilizing is meaningful, even exciting; but not nearly as dangerous as in stable autocracies that tolerate no opposition. Treaties create additional political resources for pro-rights coalitions under these circumstances; they resonate well with an embryonic rule of law culture, and gather support from groups that not only believe in the specific rights at stake, but also believe they must take a stand on rule-governed political behavioral in general. The courts may be somewhat corrupt, inexperienced, or even incompetent, but they are not nearly as likely to execute the government's will as loyally as in a stable autocracy. International human rights treaties may be in their most fertile soil under such circumstances. As we shall see, the consequences of ratification for rights compliance in these cases can be profound.

Is the claim that treaty ratification contributes to compliance via enhanced political mobilization plausible? Table 1 addresses this issue. It shows that ratification gives rise to a significant increase in local memberships in international non-governmental organizations one to four years after ratification. Ratification appears to stimulate membership in civil society organizations, even when we control for external aid, population growth, wealth, and a time trend. It is therefore at least plausible that the treaty effects discussed above have much to do with the organization of civil society demands for compliance. This interpretation is consistent with a host of case studies that describe treaties as an important tool in drawing attention to the civil rights violations of governments. ${ }^{30}$

\section{[TABLE 1 ABOUT HERE]}

In the following sections, I test for the impact of ratification of the ICCPR on three clusters of civil rights: freedom of religion, fair trials, and the right to life, as reflected in abolition

30 For a discussion of how NGOs such as HRW and ACLU use the ICCPR to criticize, e.g., the United States, see Shapiro 1993. 
of the death penalty. I have chosen these areas because they are a fairly hard test for the impact of international legal obligations on practices. Specifically, I have decided to avoid those aspects of the ICCPR that are practically synonymous with democracy itself. ${ }^{31}$ In this way, I am trying to separate treaty effects on civil rights from the more general waves of democratization that have swept most regions of the world over the course of the latter half of the $20^{\text {th }}$ century. The rights I choose to analyze are civil rights over which even democratic countries could plausibly have quite different practices and place quite different priorities. While rightly considered an “enlightenment right” the freedom to practice one’s own religion is not quintessentially an aspect of democratization, and as we will see does not vary directly with regime type. A similar point applies to the quality of criminal justice. Since most citizens will never brush up against the criminal justice system, this is an area that could easily lag behind the broader processes of “democratic development.” And yet how a society deals with persons accused and convicted of serious crimes is a central civil rights issue.

\section{Religious Freedom}

The freedom to believe in and to practice the religion of one's choice is a right with a long historical pedigree. Confessional differences were one of the earliest areas of social difference among groups - a signal distinction that was quite salient until well into the eighteenth century. ${ }^{32}$ Protection for religious minorities was an important part of the Treaty of Westphalia, ${ }^{33}$ which, however, was by no stretch of the imagination a human rights document. Still, it is probably correct to think of religious rights as among the first, if not the first, set of rights accorded first to groups and later to individuals through international legal agreements. ${ }^{34}$

Governments have been concerned about the practice and protection of religion over the centuries because it has implications for their political legitimacy and authority. As John Hall has written, "Religions deal in ultimate meanings that bear a claim to exceed merely secular authority. Thus, they remain a potent basis for contesting political legitimacy both within and beyond nation-states...”35 Governments have oftentimes feared that their authority could be

\footnotetext{
${ }^{31}$ Article 25 of the ICCPR for example provides a right "To vote and to be elected at genuine periodic elections which shall be by universal and equal suffrage and shall be held by secret ballot, guaranteeing the free expression of the will of the electors;..." Such a right is so intimately connected - practically by definition - with regime type that it makes little sense to test as an empirical outcome of a treaty commitment.

${ }^{32}$ Hannum 1991.

${ }^{33}$ Ibid.

${ }^{34}$ Humphrey 1984: 176; Partsch 1981: 209; Sieghart 1983.

35 Hall 2003.
} 
undermined by spiritual claims that transcend their temporal and territorial domain. Sociologists have discovered that political movements with religious roots typically “...originate in social strata that are negatively privileged politically and economically, or socially ascendant but blocked from power." ${ }^{36}$ Religion can and historically has served to mobilize political opposition in ways that dominant social classes or regimes view as threatening. Religious fervor and religious intolerance have historically been prime ingredients in episodes and even eras of violent conflict. ${ }^{37}$ More mundanely, governments might choose to repress even relatively powerless religious movements or individuals, in order to "reinforce general norms of cultural conformity." ${ }^{38}$ Often restrictions on religious organizations and practices involve calculated efforts to balance political control with personal freedom. The Communist Party of China's effort carefully to control certain religious practices while accepting others can be viewed as an effort to grant limited personal autonomy while trying to guard the political legitimacy of the regime, ${ }^{39}$ which is typically justified in the name of maintaining "social harmony."40

Religion has always been a social force with which governments have had to reckon. Recent surges in various indicators of religious fervor have made the issue more pertinent than ever. Throughout the former Soviet Union in the past 30 years with approximately 100 million people joined religious groups for the first time. ${ }^{41}$ According to Ronald Inglehart, scholar and Chairman of the World Values Survey, “....unequivocally... there are more people alive today with traditional religious beliefs than ever before in history, and they're [sic.] a larger percentage of the world's population than they were 20 years ago." 42

Modern states have come up with legal mechanisms for handling issues of religious freedom and its limits. Western perspectives typically assume that religious tolerance is the basis for peace; ${ }^{43}$ the separation of church and state is an oft advocated formulation. Today, as many as one-third of the nations of the world include formal guarantees of church-state separation in their constitutions. ${ }^{44}$ Even the constitutions of communist countries guaranteed freedom of

36 Ibid.

37 Some studies suggest that religious nationalism has had an especially strong association with violent conflict since the 1980s. See Fox 2004.

38 Hall 2003.

39 Potter 2003.

40 Kolodner 1994: 466.

41 Froese 2004: 57. Froese notes that this has lead not to a proliferation of religious faiths but to the unprecedented growth in religious monopolies associated with orthodox Christianity and Islam.

42 Ronald Ingelhart, chairman. “Is there a Global Resurgence of Religion?” speech before the National Press Club, May 8 2006. Transcript available at https://pewforum.org/events/index.php?EventID=116.

43 See studies by the United States Institute of Peace, discussed in Little 1996: 75.

44 Davis 2002: 223. On Latin American constitutional provisions see Sigmund 1996. 
religious belief and practice, as long as religions were not "misused” politically for opposing the (socialist) constitution. ${ }^{45}$

\section{Religious Freedom and International Law}

International law has had several responses to the issue of religious freedom. During the interwar years, Article 22 on the League of Nations Covenant imposed upon Mandatory Powers the duty to guarantee freedom of conscience and religion. ${ }^{46}$ The Universal Declaration, though not legally binding, stipulates in Article 18 that: "Everyone has the right to freedom of thought, conscience and religion; this right includes freedom to change his religion or belief, and freedom, either alone or in community with others and in public or private, to manifest his religion or belief in teaching, practice, worship and observance.” ${ }^{27}$

The ICCPR contains a number of articles that obligate state parties to respect the right of individuals to believe and practice their own religion. ${ }^{48}$ Article 2 prohibits discrimination of the rights enumerated in the Covenant on the basis of, among other things, religion, and Article 24 extends protection against discrimination explicitly to children. ${ }^{49}$ Article $20(2)$ calls on states parties to prohibit "Any advocacy of national, racial or religious hatred that constitutes incitement to discrimination, hostility or violence..."50 The most important guarantee of religious freedom is spelled out in Article 18, which provides that "Everyone shall have the right to freedom of thought, conscience and religion. This right shall include freedom to have or to adopt a religion or belief of his choice, and freedom, either individually or in community with others and in public or private, to manifest his religion or belief in worship, observance, practice and teaching.” 51 According to Article 4(2), Article 18 is one of the provisions of the treaty that is non-derogable, even in a declared national emergency. ${ }^{52}$ Interestingly, the ICCPR's Article 18 does not reiterate

\footnotetext{
45 Riis 1999: 24. Frequently, of course, a state seeking to suppress religious freedoms characterizes the activities of religious groups and leaders as impermissible political action or subversion. See Ribeiro 1987.

46 Lerner 1996: 84.

47 Universal Declaration of Human Rights, G.A. Res. 217A (III), U.N. GAOR, 3d Sess., U.N. Doc. A/810 (1948).

${ }^{48}$ Generally, see the discussion of ICCPR provisions in Lerner 2006; Tahzib 1996: 82. Religious toleration was excluded from earlier binding accords, such as the Convention on the Elimination of Racial Discrimination, because of opposition from the socialist countries at the time. See Taylor 2005: 9.

49 ICCPR, Article 2, para. 1; Article 24 para 1; see also Article 26.

50 ICCPR Article, para. 2.

51 ICCPR Article 18, para. 1. The right to practice one's own religion is also guaranteed in Article 27. There are permissible limitations on the right to "manifest" ones religious beliefs. See discussion in Taylor 2005: 292-338.

52 ICCPR, Article 4, para. 2
} 
the UDHR's language specifying a right to change religions - a provision that was opposed by Saudi Arabia and other conservative Muslim countries. ${ }^{53}$

Several regional agreements also contain provisions about religious freedom. ${ }^{54}$ Article 9 of the 1950 European Convention almost replicates Art 18 para 3 of the ICCPR. The Organization on Security and Cooperation in Europe's Principle VII of the Helsinki Final Act refers to freedom of thought, conscience, religion and belief for all without distinction as to race, sex, language or religion. ${ }^{55}$ The 1960 American Convention on Human Rights provides for freedom of conscience and religion (Article 12), and proclaims the right to maintain and to change one's religious beliefs. ${ }^{56}$ Article 8 of the African Charter guarantees free conscience and the free practice of religion. ${ }^{57}$

Islamic agreements referring to religious freedom are much more circumspect. While agreeing to the principle of freely chosen religious commitments, they evince a real concern with conversion from Islam to other belief systems. The Cairo Declaration on Human Rights (1990) prohibits "any form of compulsion on man or to exploit his poverty or ignorance in order to convert him to another religion or to atheism" (Article 10). ${ }^{58}$ Article 22 allows freedom of expression as long as it is exercised in a manner that is not contrary to the principles of Shari'a. ${ }^{59}$ Religious freedom is sharply curtailed in certain Islamic theologies, according to some scholars,

53 Tahzib 1996: 85. "The Saudi Arabian representative argued that explicit recognition of freedom to change one's religion or belief would foster discrimination in favour of religions possessing highly organized proselytizing institutions, particularly in the case of a state with a proselytizing state religion." (p. 85). To quote the Saudi delegate, "Men could in fact be induced to change their religion not only for perfectly legitimate intellectual or moral reasons, but also through weakness or credulity." UN Doc A/C.3/SR.1021, para 27. See also Taylor 2005: 29-34.

54 These are discussed in Lerner 2000: 40-50.

55 The Final Act of the Conference on Security and Cooperation in Europe, Aug. 1, 1975, 14 I.L.M. 1292 (Helsinki Declaration); text at http://www1.umn.edu/humanrts/osce/basics/finact75.htm. Furthermore, "The monitoring of human rights by the Council of Europe, the OSCE, and the EU has produced significant case law with respect to religious rights. Ibid.: 42. For a comparison of international and European law on religious freedoms see generally Taylor 2005.

56 Statute of the Inter-American Commission on Human Rights, O.A.S. Res. 447 (IX-0/79), O.A.S. Off. Rec. OEA/Ser.P/IX.0.2/80, Vol. 1 at 88, Annual Report of the Inter-American Commission on Human Rights, OEA/Ser.L/V/11.50 doc.13 rev. 1 at 10 (1980), text at http://www1.umn.edu/humanrts/oasinstr/zoas4cms.htm.

57 African [Banjul] Charter on Human and Peoples' Rights, adopted June 27, 1981, OAU Doc. CAB/LEG/67/3 rev. 5, 21 I.L.M. 58 (1982), entered into force Oct. 21, 1986; excerpted text at http://www1.umn.edu/humanrts/instree/z1afchar.htm.

58 Cairo Declaration on Human Rights in Islam,Aug. 5, 1990, U.N. GAOR, World Conf. on Hum. Rts., 4th Sess., Agenda Item 5, U.N. Doc.

A/CONF.157/PC/62/Add.18 (1993) [English translation]; Article 10. Text at http://www1.umn.edu/humanrts/instree/cairodeclaration.html.

${ }^{59}$ Cairo Declaration, Article 22. 
by the view that conversion from Islam to another religion is tantamount to treason, and potentially punishable by death. ${ }^{60}$

More than a decade after the ICCPR opened for signature, the General Assembly passed a (non-binding) resolution that filled out some of the details of the religious clauses of the ICCPR. In 1981, the UNGA adopted by consensus the Declaration on the Elimination of All Forms of Intolerance and of Discrimination Based on Religion or Belief. Its main purpose is to give more concrete content to the general norms of the Universal Declaration and the Covenant on Civil and Political Rights. ${ }^{61}$ UN-based law on religious freedom is also reiterated in the Convention on the Rights of the Child, which acknowledges children's "freedom to manifest [their] religion or religious beliefs" (Article 14), although this is the most reserved against provision of that convention. ${ }^{62}$

Despite these international legal obligations, it is not at all obvious that governments have taken practical measures to improve religious freedom within their jurisdictions. In 1986, a study of UN members' constitutions found that most had in fact provided for the protection of religious freedoms in their national constitutions and guarded against religious discrimination in their penal codes - though very few countries were judged to have implemented these measures in a satisfactory way in practice. ${ }^{63}$ State control over religious groups in Communist China has long been notoriously tight and treatment of many religious groups especially harsh. ${ }^{64}$ Some countries, such as Russia, have ratified the ICCPR but have also recently implemented domestic laws on religious freedom that are noticeably more restrictive. ${ }^{65}$ In fact, as Peter Beyer has noted, “...maintenance of some kind of religious hegemony is the rule all across global society... unfettered freedom of religion or genuine religious pluralization is correspondingly rare, if it exists anywhere.”66 Even liberal democracies such as Germany and France have taken actions that to some extent discriminate against or suppress religious groups and practices. ${ }^{67}$ Richard Lillich has concluded that “...one is forced to acknowledge that the right of religious freedom is

\footnotetext{
60 Talbi 1986: 182.

61 Article 1 affirms the right to freedom of thought, conscience and belief, and the right to manifest one's religion or belief. Article 2 prohibits discrimination on the basis of religion or belief. Neither provision defines "religion" or "belief," nor are these terms defined elsewhere in the Declaration. See the discussion in Sullivan 1988. See also Lerner 2000: 20-28; Odio Benito 1989: 48-50.

62 For a discussion of religious rights of children, see Brems 2006.

63 Odio Benito 1989: 22-30.

64 Evans 2002.

65 Durham and Homer 1998. Some scholars compare the restrictive 1997 law as a return to religious restrictions during the Stalin era. See Froese 2004: 69.

66 Beyer 2003.

67 On Germany, see Editorial 1998.; On Frances “Anti-Sect” Bill, see http://www.cesnur.org/testi/fr2K_july4.htm.
} 
one of the weakest - from the point of view of its recognition and its enforcement - of all the rights contained in articles 3-18 of the Universal Declaration." ${ }^{\text {68 }}$ Does it matter for the enjoyment of religious freedom that governments have committed themselves to the ICCPR?

\section{Data and Methods}

While no society can be characterized by the perfectly free practice of religious beliefs even the hyperliberal United States curtails religious practices considered immoral or a public danger - it is reasonable to expect that governments who have committed themselves to the International Covenant on Civil and Political Rights to move in the direction of a relatively more liberal approach to religious belief and practice. In order to test this proposition, it is necessary to measure the relative liberality of official practices. Data collected by Cingranelli and Richards provides one such measure. Their religious freedom indicator measures "the extent to which the freedom of citizens to exercise and practice their religious beliefs is subject to actual government restrictions. Citizens should be able to freely practice their religion and proselytize (attempt to convert) other citizens to their religion as long as such attempts are done in a non-coercive, peaceful manner."69 This variable is dichotomous; that is, countries are coded as either restrictive or free. Governmental practices that count as restrictions include prohibitions on proselytizing, prohibitions on clergy's political participation; the arrest, detention or violence toward religious officials, citizen conversions forced by government officials, citizen arrests, harassment and/or intimidation for religious beliefs and practices, and so forth.

\section{[FIGURE 2 ABOUT HERE]}

The worldwide average relationship between this measure and ratification of the ICCPR is depicted in Figure 2. There appears to be no clear relationship between ICCPR ratification, which has trended upward over time, and this average measure of religious freedom worldwide. Religious freedom worldwide seems to take a dive between 1985 and 1987, and then improves slightly in the earliest post-Cold War years, only to drift downward over the course of the 1990s and early 2000s. Obviously more than international legal developments are at play here. But the question is, given the broad range of pressures on governments to accommodate or to repress free religious practices, how, if at all, has ratification of the main binding global instrument - the ICCPR - influenced actual practices?

68 Lillich 1984: 60.

69 See description at http://ciri.binghamton.edu/documentation/ciri_variables_short_descriptions.pdf 
In order to address this question, I use a two-stage regression model in which ratification in the region, common law legal system, and ratification procedures are used as instruments for ratification. ${ }^{70}$ Country fixed effects are included as controls but not reported. A lagged dependent variable is also included, so that we are in effect modeling improvements in religious freedom from year to year.

A number of control variables are included so as to reduce the risk of drawing inappropriate inferences about ICCPR commitment. An indicator is included to capture the extent to which the state has a constitutionally established relationship with an official religious organization. I distinguish those states that established an official religion between 1970 and 2000, from those that disestablished an official religion in the same time period. My expectation would be that establishment would be associated with more governmental interference in free religious practices, which disestablishment would be associated with a liberalizing trend. I also distinguish states that were stable with respect to the establishment of state religion between 1970 and 2000, although I have no clear expectation for trends in their repression. After all, there is no reason to expect religious repression/freedom in a country to change much where relations between church and state are fairly stable. ${ }^{71}$

One of the most important conditions for which to control is the extent of societal homogeneity with respect to religious culture. In societies characterized by a high degree of homogeneity, state repression will hardly be necessary to achieve a consensus on basic value and social issues. But where many religious groups vie for social or cultural space, politicians may decide to use repression to advantage their religious supporters and quash culturally based opposition. The greater the degree of religious fractionalization, the greater we might expect religious repression to be.

I also control for the dominant religion within each country. Certainly, no particular religious orientation has a monopoly on repressive tactics, whether for political or for spiritual reasons. Yet it remains true that certain of the world's major religions are "universalistic" in orientation; in Ole Riis's words, they “claim to contain the whole spiritual truth, [while] particularistic religions have more specific aims and only claim partial access to that truth.” 72 Riis goes on to contend that "While the former confront the individual with a fundamental choice and demand total commitment from their members, the latter are less demanding and may even

70 For a justification of these as good instruments - they explain ratification but do not directly explain the rights outomes in question - see Simmons forthcoming: ch. 3 .

${ }^{71}$ Ironically, the motive behind establishment of a particular state religion usually is to strengthen that religion, but the effects are ultimately to undermine the vitality of the established religion. Establishing a state religion tends to reduce actual religious attendance. See North and Gwin 2004.

${ }^{72}$ Riis 1999: 23. 
be combined in functional mixtures, which, for the universal religions, would be perceived as eclecticism, syncretism and heresy. As a consequence, religious pluralism seems to be less problematic when particularistic religions are involved." ${ }^{73}$ For these reasons, I include indicators for predominantly Protestant, Catholic and Islamic countries. If Riis's observation can be generalized, we might expect countries dominated by these faiths to be relatively intolerant of, and possibly even repressive toward, religious minorities.

External pressures could also account for some episodes of liberalization toward religious belief and practice. Some of the wealthiest countries in the world are the most democratic and among the staunchest supports of rights world wide. Some of these governments are likely to use their aid strategically to oppose minority repression of all kinds; religious freedom would be only one among many of these governments' goals. In addition, foreign aid in some countries - the United States in particular - may have been influenced by religious Christians intent on punishing governments that take a harsh stance against Christian churches and missionaries. ${ }^{74}$ Aid given by external actors could easily be conditioned - whether implicitly or explicitly - by demands that recipients honor the religious rights of their locals (and of foreign missionaries). The more important such aid is as a proportion of GDP, the more we might expect an improvement in religious freedom, quite independent of the demands associated with treaty ratification.

\section{Findings: ICCPR Ratification and Religious Freedom}

The results of these analyses are displayed in Table 2. One thing is quite clear: there are many factors that impact government policies with respect to religious freedom than the ratification of the ICCPR. Models 1-3 indicate that ratification is positively associated with minimal governmental restrictions on religious freedoms, although the result is statistically significant on average only five years after ratification. Models 3-5 run a similar model on subsets of countries: transitioning countries, stable democracies (since World War II), and stable autocracies. These tests show that the transitioning group - countries that have at some point since World War II have experienced a modicum of democratic governance - account for the most convincing share of the effects of ICCPR ratification. According to Model 4, we can be fairly sure that among transitioning countries, ratification of the ICCPR is associated with an 11 percent increase in the average religious freedom score. If anything, ICCPR ratification is associated with a slight deterioration in freedom in stable democracies $(\mathrm{p}=.165$, below standard levels of statistical significance), while in stable autocracies, the standard error is far too high to

${ }^{73}$ Ibid.: 23-24.

74 Martin 1999. 
draw any inferences at all. Ratification of the ICCPR is most convincingly associated with improvements in religious freedoms in countries in transition. These results are robust to the inclusion of country and year fixed effects, a year trend, the actual degree of democracy in each year, and average religious freedom in the region. ${ }^{75}$

\section{[TABLE 2 ABOUT HERE]}

Of course, much else explains governments' efforts to control religious beliefs and practices in their jurisdictions. The changing relationship between church and state over time appears to be quite important, but it varies significantly across subgroups by regime type. Establishment and disestablishment were associated with greater governmental restrictions on religion in general, but not within stable democracies, where these changes seem to make no systematic difference to religious freedoms. Generally, in countries with a high degree of religious fractionalization, there tends to be much more official state oppression than in more religiously homogenous societies, but the stable autocracies account for most of the repression in this case. For an autocrat, religious opposition might well represent a perceived political threat, “justifying” a crack down on the religious followers of political rivals.

Foreign aid also seems to work, as expected: as aid increases as a proportion of the recipient's GDP, governments tend to remove restrictions and take a more liberal approach to religious freedoms. This result is especially strong for autocracies, though weak to non-existent within stable democracies. A strong possibility is that aid is given selectively, that is, to countries that already have fairly strong respect for religious freedoms. It could also indicate a form of soft conditionality if aid providers extend assistance on the understanding that rights practices with respect to religious freedoms are expected to improve. Surprisingly, a country's level of development seems to be negatively associated with religious freedoms: controlling for differences between countries, and focusing only effects within them, greater wealth per capita is associated with more governmental interference with religious freedom.

Finally a word about religious freedoms across the major religious cultures. Because they span many nations, I have tested for differences in practices with respect to religious freedom for predominantly Protestant, Catholic, and Islamic nations. No predominantly Islamic countries were among the stable democracies, but neither branch of Christianity had any significant impact on religious freedoms in stable democracies. Predominant religious culture in the transitioning countries and stable autocracies display contrasting results, with Islam associated

75 For brevity, these results are not shown here. 
with greater religious freedoms among transitioning countries and Christianity associated with greater religious freedom among stable tyrants.

For our purposes, the major result is the weak but noticeable influence of ICCPR within five years of ratification for all regime types, with a clear concentration of these positive effects within countries that have had at least some post war experience with a moderate level of democratic governance. This is consistent with a theory that predicts the strongest treaty effects iin countries in which individuals and groups have both the motive and the means to demand treaty adherence. It is also consistent with anecdotal evidence of the weight that at least some religious groups attach to ratification of the ICCPR as a way to enhance their ability to operate freely in many locations throughout the world. ${ }^{76}$ Indeed, the ability to organize and to draw from the strength of faith-based communities with dense social networks may be one of the key reasons the ICCPR's religious guarantees are more difficult for governments to ignore than other aspects of the treaty. A fairly sharp comparison can be drawn with civil rights touching on criminal justice, which is explored in the following sections.

\section{Fair Trials}

The right to a fair trial has deep historical roots that extend back as far as the Magna Carta (1215). ${ }^{77}$ The idea of that document - and many to follow with successively greater elaboration and expansion - was to prevent the arbitrary exercise of sovereign power to arrest, detain and convict individuals for various infractions and misdeeds without basic provisions for the due processes of law.

So why do some states fail to provide their populace access to a fair trial? One cluster of explanations resides in the generally repressive nature of governance on which some regimes rely. Denying access to justice for political opponents to common criminals is one way for an oppressive state to maintain its arbitrary control over social and political developments. Demands

\footnotetext{
${ }^{76}$ Among US religious and church organizations, the more liberal - often those whose organizational provenance can be traced to the anti-war movement of the Vietnam era - tend to support the ratification of the ICCPR and other covenants, while more conservative religious organizations such as the National Association of Evangelicals, are distinctly cool to the UN approach to rights. See the discussion in Livezey 1989. For more on the follow-up of religious as well as secular NGOs, see Tahzib 1996: 245. and generally discussion on pp. 223-245. See also Roan 1996.

77 "No free man shall be seized or imprisoned, or stripped of his rights or possessions, or outlawed or exiled, or deprived of his standing in any other way, nor will we proceed with force against him, or send others to do so, except by the lawful judgment of his equals or by the law of the land.” Magna Carta, Article 39. Text can be accessed at http://www.fordham.edu/halsall/source/magnacarta.html. (Accessed September 27, 2007.)
} 
for fair treatment before the law have historically been associated with a break with arbitrary or authoritarian rule. Fair trials were central among the liberties that distinguished the colonial rights of Englishmen in the New World on the eve of the American Revolution. ${ }^{78}$ Fair trials were also a centerpiece of the democratic transition in former Communist countries, such as the Czech Republic, Hungary, Poland, Lithuania and Romania, and made their way prominently in to the new post-Communist constitutions in these state. ${ }^{79}$ A right to a fair trial was not included in the South African constitution until apartheid was brought down in 1994; such a right as existed in common law in that country could be overridden legislatively according to principles of parliamentary sovereignty. ${ }^{80}$ The concept of popular sovereignty historically has fueled demands for legal reforms that reflect the basic civil right to due process of law for individuals accused of crimes. $^{81}$

There may be other reasons for weak due process in practice. Some observers associate a breakdown in the fair delivery of criminal justice with a broad incapacity of organs of justice more generally. In parts of Asia, fair trials are seen as a symptomatic of the widespread demise of judicial independence more generally. ${ }^{82}$ In particular, some countries are plagued with judicial incompetence and poor police training. ${ }^{83}$ The provision of a fair trial may be limited not only for political purposes of despotic states, but can also flow from bureaucratic incapacities that stem from broader resource deficiencies.

\section{Fair Trials in International Law}

The Universal Declaration of Human Rights was the first modern multilateral document to articulate a right to a fair trial. Fair trials were somewhat less controversial than the provision of religious freedom, though debates did ensue about the exact parameters of this guarantee. The United States was eager to articulate post-war principles of civil and political rights, and provided the first proposal containing some of the substantive fair trial provisions for the UDHR. ${ }^{84}$ The United Kingdom drafted provisions for protections from arbitrary arrest. ${ }^{85}$ Delegations from Cuba, Chile, and Mexico were also especially active in the drafting of fair trial provisions, and

\footnotetext{
78 See Bodenhamer 1992: 19.

79 See articles by Hollander, Vasilescu and Trocsanyi, Staciokas, Oniszczuk and Horvath in Council of Europe 2000.

80 Skeen 2000: 110.

81 Sung 2006.

82 See the rambling and disorganized discussion in Asian Human Rights Commission 2000.

83 As an example, see the statistics regarding Nepal cited in Sangroula 2000.

84 These provisions, though developed specifically for the UDHR, were eventually adopted in the ICCPR's Article 14, the development of which the US was decidedly cool. See Weissbrodt 2001: 44. 85 Ibid.
} 
were insistent on their inclusion. As a result of these efforts, fair trials feature prominently in the UDHR: Article 8 provides for remedies for violations of the right to a fair trial; Article 9 deals with arbitrary arrest; Article 10 expresses the basic right of the individual to a fair trial in both civil and criminal proceedings; and Article 11 refers to a presumption of innocence and the prohibition of ex post facto laws and penalties. ${ }^{86}$

The ICCPR was negotiated concurrently with the Universal Declaration, and the UDHR's articles 8-11 were made legally binding in Articles 14 and 15 of the Covenant. "All persons shall be equal before the courts and tribunals. In the determination of any criminal charge against him, or of his rights and obligations in a suit at law, everyone shall be entitled to a fair and public hearing by a competent, independent and impartial tribunal established by law,” according to Article $14{ }^{87}$ Article 15 guarantees a presumption of innocence and prohibition of ex post facto laws, and is one of the seven articles specified as non-derogable in Article $4 .{ }^{88}$ The ICCPR also addresses some events leading up to and following the trial proper, including arrest, detention, interrogation, and punishment. ${ }^{89}$ According to the Human Rights Committee, the object and purpose of these provisions, and especially Articles 14 and 15, is to ensure that no one is subject to arbitrary prosecution, conviction, or punishment. ${ }^{90}$

Fair trials are also mentioned in several regional human rights agreements. The Americas were among the earliest to institutionalize a right to a fair trial on a regional basis. The 1948 American Declaration of the Rights and Duties of Man mentions a fundamental right to access the courts "to ensure respect for his legal rights"91 while the American Convention on Human Rights provides for a liberal list of "minimal guarantees” for “[e]very person accused of a criminal offense...” ${ }^{92}$ Article 6 of the 1953 European Convention for the Protection of Human

86 See UDHR, articles 8-11.

87 Article 14. On the origins and drafting history of Article 14 see Weissbrodt and Hallendorff 1999.

88 See the discussion in Weissbrodt 2001: 93-110.

89 See Articles 4, 6-11, 17 and 26

90 Accordingly, they have interpreted the provisions as applying both to general courts and to specialized courts (e.g., military tribunals) that try civilians, and view fair trial provisions as pertaining to violations made at any stage of the proceedings. Human Rights Committee General Comment 13 (21) (adopted in 1984), UN doc HRI/GEN/1/Rev.2 (1996). Text located at http://www1.umn.edu/humanrts/gencomm/hrcom13.htm. For a discussion of the various fair trial provisions of the ICCPR, see De Zayas 1997; Jayawickrama 1997; van Dijk 1983.

91 American Declaration of the Rights and Duties of Man, O.A.S. Res. XXX, adopted by the Ninth International Conference of American States (1948), Article XVIII. Text at http://www1.umn.edu/humanrts/oasinstr/zoas2dec.htm.

$\overline{92}$ American Convention on Human Rights, O.A.S.Treaty Series No. 36, 1144 U.N.T.S. 123, entered into force July 18, 1978, Article 8, para. 1 and 2. Text available at http://www1.umn.edu/humanrts/oasinstr/zoas3con.htm. For a discussion of cases heard by the InterAmerican Commission on Human Rights and the Interamerican Court of Human Rights see Augusto Cancado 1997; Kokott 1997. 
Rights and Fundamental Freedoms (as amended), which preceded, the ICCPR, specifies a right to a fair trial, and describes this right in much the same way as does the ICCPR. ${ }^{93}$ The League of Arab States' Charter on Human Rights (as revised, 2004) also contains guarantees with respect to fair trials. ${ }^{94}$ Article 7 of the African Charter includes rights to be presumed innocent, to defense and counsel of accused's choice, the right to an impartial trial within a reasonable period of time and protection from ex post laws, but does not contain many of the other components of a fair trial specified in the UDHR and the ICCPR. ${ }^{95}$ The right to a fair trial is also addressed under international humanitarian law, in particular the Geneva Conventions (1949) and their 1977 Protocols. $^{96}$

The ICCPR remains the most important universal treaty to guarantee a right to a fair trial. What has the ratification of the ICCPR contributed to the actual provision of a fair approach to criminal justice? The strategy for answering this question is discussed in the following section.

\section{Data and Methods}

If the ICCPR has an influence on the civil rights of accused persons, then we should see actual practices guaranteeing fairness to improve among ratifiers. Oona Hathaway has developed a sophisticated measure of fair trials, using international legal texts - primarily the ICCPR - as her guide and State Department reports for the raw material from which her index is coded. ${ }^{97}$ The index considers the extent to which trials are carried out by independent and impartial tribunals; whether an accused person has a right to counsel (and if necessary, an interpreter) and to present a defense; whether there is a presumption of innocence; the trial is held publicly, in a timely fashion and with a right to appeal. In addition, she coded for prohibitions on ex post facto laws and the right to have charges presented with prior notice. ${ }^{98}$ This index captures well the international norms embodied in the ICCPR.

Figure 3 illustrates the world-wide average of the Fair Trials scale each year from 1982 to 2002. We only have data since 1982, but the trends are toward a slight deterioration in the mid

\footnotetext{
93 Convention for the Protection of Human Rights and Fundamental Freedoms, 213 U.N.T.S. 222, entered into force Sept. 3, 1953, as amended by Protocols Nos 3, 5, 8, and 11 which entered into force on 21 September 1970, 20 December 1971, 1 January 1990, and 1 November 1998 respectively. See http://www1.umn.edu/humanrts/instree/z17euroco.html. See discussion in Leigh 1997; Matscher 2000.

94 See articles 13 (paras. 1 and 2) 14 (5),16, 17, and 20(2). League of Arab States, Revised Arab Charter on Human Rights, May 22, 2004. Text available at http://www1.umn.edu/humanrts/instree/loas2005.html. 95 African [Banjul] Charter on Human and Peoples' Rights, adopted June 27, 1981, OAU Doc. CAB/LEG/67/3 rev. 5, 21 I.L.M. 58 (1982), entered into force Oct. 21, 1986. See discussion in Badawi ElSheikh 1997: 328.

96 Swinarski 1997.

97 On the quality of state department reports see De Neufville 1986.

98 For the original coding justification see Hathaway 2002.
} 
1980s and again in the late 1990s. On the face of it, it would appear there is very little relationship between average global ratification of the ICCPR and the average on this scale, in contrast to the broader civil liberties measure examined above. Of course, many factors influence the will and capacity to provide individuals accused of a crime with a fair trial. What if anything does ratification contribute?

\section{[FIGURE 3 ABOUT HERE]}

In order to answer this question, it is again important to construct a model that accounts for ratification endogeneity, constant characteristics of countries, shocks specific to particular years, and a host of alternative explanations. The models reported in Table 3 pool countries over time and employ two-stage least squares, and endogenize the decision to ratify the ICCPR as described above. ${ }^{99}$ They all contain country fixed effects, so that constant characteristics of particular countries do not drive results; as well as year fixed effects, to control for the possibility that some common external shock jolts all countries to alter their policies at given points in time. To account for policy inertia, the dependent variable lagged three years is included, as are average regional trial practices to account for the possibility of socialization or mimicry toward regional norms. Since we do not want to confuse the effects of ICCPR ratification with the general processes associated with democratization, variables to capture both democratic levels and change are included. Since it is reasonable to assume that fair criminal justice is more likely to be suspended during national emergencies, civil and international wars are included. Fair trials could also be a function of development level (GDP/capita) or external influences, such as development assistance; both of these are controlled in what follows. In addition, I control for extraordinary efforts to improve government accountability with respect to human rights practices with controls for truth commissions and criminal trials aimed at prosecuting officials for criminal human rights violations. As above, robust standard errors with a correction for clustering on country are reported.

Oona Hathaway pioneered research in this area, and found that ratification of the ICCPR had little effect on state practices with respect to fair trials. Quite the contrary: some analyses of her evidence suggest that rights practices worsen once a treaty commitment has been made. However, I am interested not only in the aggregate effects of the ICCPR with respect to fair trials,

${ }^{99}$ Unfortunately, in this case, the common law variable is unlikely to make a good instrument. According to some legal scholars, the idea of a fair trial for those accused of crimes is a contribution of the common law tradition, with its emphasis on "fair play." See for example Matscher 2000: 10. Thus, identification in this case depends almost exclusively on regional ratification density in the previous period. 
but also in the conditions under which we might expect ratification to have its strongest impact. Theoretically, there are strong reasons to suspect that fair trials are already provided in stable democracies, and there is little reason for ratification of the ICCPR to stimulate new political demands in that regard. Nor should we expect the ICCPR to make much difference in stable autocracies, where potential demandeurs can anticipate costly state resistance. Ratification should matter most where local groups have both the motive and the means to demand compliance. This is the case in countries characterized by some degree of regime transition.

\section{Findings: ICCPR Ratification and Fair Trials}

\section{[TABLE 3 ABOUT HERE]}

The results for the influence of ICCPR treaty commitments are reported in Table 3. With one exception, in every version of the model, ICCPR ratification is associated with improvements in fair trial practices. However, when all countries are included in the sample, the result does not meet traditional standards of statistical significance. Interesting variation emerges, however, when we look at subgroups of countries. Ratification of the ICCPR appears to have no discernable effects in countries that were never democratic during the post World War II period, nor in stable democracies over those years. But if we run a similar test for countries that had had some experience with democratic politics - transitional countries in the sense that they had passed a moderately high democratic threshold at some point in the post war years - ratification of the ICCPR is quite likely to be associated with fairer domestic trials from year to year, at least in the short run. When we look for impact five years out from ratification, the ICCPR effect becomes swamped by other factors. Nevertheless, there is some evidence that for the fifty-five counties coded as transitional, ratification has contributed to better practices - fairer trials for individuals than would have been the case had the treaty not been ratified at all.

Ratification of the ICCPR is of course not the only influence on fair trials, and the control variables tested here reveal some important influences on legal practices. The usually strongly positive lagged dependent variable indicates that countries with poor ratings were likely to have poor ratings in the next period, indicating that the fairness of trials is marked by a high degree of institutional inertia. The most consistent external influence across all categories of countries is the

nature of the practices in the region in which the country is situated. Across all subgroups and the sample as a whole, fair trial practices in the region were a strong predictor of fair trial practices in a specific country. This effect appears to be the strongest among transitional countries, though it 
is statistically significant in every model. This pattern could be explained by shared cultural patterns or even regional socialization or mimicry. Another external influence that is strongest in transitional countries is the positive influence of overseas development assistance. But it is important to note that the effects of the ICCPR are noticeable among the transitional countries even when controlling for their regional context and foreign development aid.

One of the most important influences on fair trial practices is the nature of the domestic political regime, but the results hold some surprises in this regard. A country's extent of democracy at the time of observation does not have the positive effect on fair trials one might expect (except among those countries that have been stable democracies since World War II). Even more surprising, democratic change tends to lead to worse fair trial practices in the following year, and this result is especially robust for the 55 transitional countries. What these results suggest is that in practice fair trials do not improve in lock-step with democracy and democratic improvements. Protecting the legal rights of the accused requires something more than encouraging participatory democracy. More in line with expectations, civilian governments are more likely to be associated with fair trials. Legal fairness appears to deteriorate significantly, especially for countries in transition governed by military leaders. (Note that there were no military governments among the stable democracies, so the variable drops out of that model.) There is also some evidence that governments especially committed to exposing the crimes and abuses of earlier regimes through the use of truth commissions also improve their trials in the following year. Unsurprisingly, countries that score high on the rule of law scale also tend to provide fairer trials for accused persons. The inclusion of these variables helps to control for a domestically generated commitment to improve human rights practices, and increases our confidence that the ICCPR ratification variable is not simply reflecting a set of domestic legal innovations.

There is little evidence that fair trial practices are driven by what might broadly be considered developmental or local social factors. While it undoubtedly takes resources to hold fair trials - providing the defense with qualified attorneys and educating independent judges is not a low cost option - it is not the case that wealthier countries conduct fairer trials, all else equal. In fact, there is some suggestion that the opposite is true, at least for the more authoritarian regimes. Countries that are more varied in terms of religion, language, and ethnic groups may tend to have somewhat better practices as well, but this result seems to be driven by the stable democracies, such as Belgium, among them. A burgeoning population may contribute to deteriorating practices if social and other problems worsen, though in this case the effects seem to 
be concentrated in the stable autocracies. Overall, however, it is hard to say there is a clear social or developmental country profile associated with fair trials.

Far clearer is the role that violent conflict plays in the administration of justice for the accused. The expectation that violent periods of "national emergency" are often used as reasons to short-circuit normal rights protections in the name of national security is born out in these tests. Both civil wars and interstate wars returned the expected negative coefficient for the sample of countries as a whole, but the most consistent deterioration in rights is associated with war is concentrated in the countries that were never democratic during the post war years. The effect is apparently contradictory for stable democracies, with civil wars associated with worse practices and international wars with fairer trials. In the transition countries, wars - whether civil or international - are not associated with clear trends in fair trials in either direction.

Overall, the influence of ICCPR ratification on fair trials is highly conditioned by the nature of the regime. There is a mild positive but statistically insignificant association across all countries, but the analysis of subgroups indicates that the positive effects are concentrated largely in neither the stable democracies nor the stable autocracies, but rather in those polities that have had some experience with democratic government, however fleeting. The statistical strength of the relationship is not very strong - we can only be 91-92\% confident that the relationship is not due to chance alone - but it does offer some evidence that ratification is associated under the right political circumstances with actual improvements in fair trials, as required by the ICCPR.

\section{Cruel and Inhumane Punishment: The Death Penalty}

A final area to consider governed by the International Covenant on Civil and Political Rights, and especially its optional protocol, is that of cruel and inhuman punishment. Specifically, this section will inquire into compliance with international legal commitments to abolish capital punishment, or the penalty of death for the commission of a crime.

The death penalty is one of the oldest forms of criminal punishment. Laws providing for the death penalty date from the $18^{\text {th }}$ century BCE in Babylonia. In $7^{\text {th }}$ century BCE Athens, the Draconian code made death the only punishment for all crimes. In a less absolute form, capital punishment became part of Roman law in the $5^{\text {th }}$ century BCE, and has been used throughout much of the world for most of recorded history. ${ }^{100}$ The death penalty is referred to in sacred texts from the Bible to the Koran. Some anthropologists count capital punishment as a "universal

100 For a concise historical overview, see the introduction to Schabas 2002. 
cultural trait” alongside families and religion, viewing it as common at some point in time to all known cultures. ${ }^{101}$

Enlightenment thought ushered in a trend toward greater circumspection regarding the death penalty. The most influential work of the period was penned by the Italian criminologist, Cesare Beccaria, who emphasized both its futility and inhumanness. ${ }^{102}$ By the $19^{\text {th }}$ century, governments began to view the practice much more critically. There were practical reasons to curtail the widespread practice of execution as well. Many a poor British citizen was hung in London in the $18^{\text {th }}$ century, though the main reason Britain had to curtail public hangings is alleged to be not a humanitarian concern, but the problem of numbers. ${ }^{103}$ Soon, developments in long distance transportation made it possible to export rather than execute offenders - an option embraced by abolitionists in England. ${ }^{104}$ Opposition to the death penalty began to develop elsewhere in the western hemisphere as well. Michigan became the first jurisdiction to abolish the practice permanently, in $1864 .{ }^{105}$ Venezuela was one of the first countries to remove the death penalty for all crimes (1863), and several countries in Latin America and Europe followed by eliminating the death penalty at least during peace time - Portugal being the first in Europe to do so in $1864 .^{106}$

The movement to abolish the death penalty gained momentum after World War II. What distinguishes this period of abolition from the past (when it was considered an internal matter) is the largely European-driven effort to use international treaties to bring about abolition. ${ }^{107}$ As discussed in further detail below, since 1983, the Council of Europe has banned the death penalty, and accession to that ban is a condition for joining the European Union. ${ }^{108}$ In Europe, the discourse of "civilization" and human dignity has framed the death penalty debate. ${ }^{109}$ Largely as a result of this frame, Europe was a "de facto death-penalty-free continent” by the year 2000.” 110 Among democracies, the United States stands out as the most important country to oppose the European effort to eliminate the death penalty worldwide. ${ }^{111}$

101 Otterbein 1986: 37-45.

102 Beccaria 1963.

103 Linebaugh 1991. Gatrell 1994.

104 Ekirch 1987.

105 On the historical background see Davis 1957.

${ }^{106}$ On the abolition of the death penalty in Europe see Ancel 1962: 8-14. On the history of death penalty abolition in the Americas see Bowers et al. 1984: 146.

107 Hood 2001: 337. Boulanger and Sarat 2005.

108 See http://ec.europa.eu/external_relations/human_rights/adp/index.htm.

109 Boulanger and Sarat 2005: 32.

110 PUHAR 55

${ }^{111}$ For an interesting discussion of US attitudes toward the death penalty see Zimring 2003: 42-64. See also Baumer, Messner, and Rosenfeld 2003. 
Outside of Europe, the death penalty remains widespread, in law and in practice. It continues to be used in countries as culturally diverse as China, Islamic countries, and the United States. ${ }^{112}$ By some accounts the abolitionist movement reached a plateau by the late $1990 \mathrm{~s} .{ }^{113}$ In some cases, there have even been reversals (in Gambia, Kansas and New York, for example). As Roger Hood has written, there is nothing inevitable about the process of abolition. ${ }^{114}$

A range of theories have been advanced to explain the retention of the death penalty. Some scholars emphasize its role in consolidating political legitimacy, ${ }^{115}$ while others link it with religious beliefs about the inappropriateness - or the moral necessity - of earthy retribution. ${ }^{116}$ One thing does seem apparent: while numerous studies have shown that repressive governments are more likely than liberal ones to have and use capital punishment, ${ }^{117}$ there is no necessary link between democracy and the decision to abolish the death penalty. Stable democracies (from the United States ${ }^{118}$ to Jamaica to Japan ${ }^{119}$ ) as well as some of the most oppressive autocracies (from China to Iran to Tajikistan) retain the death penalty for ordinary crimes. ${ }^{120}$ And it is quite clear that the demand for abolition is not typically linked to popular democratic forces. In 1975, some $85 \%$ of Britons polled said they favored the death penalty in their country; even though it had been repealed a decade earlier. ${ }^{121}$ In much of Eastern Europe, the death penalty was repealed, despite the fact that public opinion often supported it; ${ }^{122}$ in many cases change was wrought through constitutional courts rather than parliamentary decision. ${ }^{123}$

This ironic situation - abolition often against prevailing public preferences - is one of the most intriguing aspects of this issue area. Democratic governments are often willing to abolish capital punishment, despite fairly broad public support for it in many cases. Despite the moral

\footnotetext{
112 See the discussion in Wyman 1997. Hood notes that it is misleading to speak of "the" United States in this regard since the death penalty is largely regulated by the states. Hood 2001: 343.

113 Radzinowicz 1999: 293.

114 Hood 2001: 333-35.

115 Miethe, Lu, and Deibert 2005; Otterbein 1986: 37-45; 73; Ruddell 2005.

116 Jacobs and Carmichael 2004; Miethe, Lu, and Deibert 2005; Potter 1993; Soss, Langbein, and Metelko 2003.

117 Miethe, Lu, and Deibert 2005; Ruddell and Urbana 2004.

118 Some authors have emphasized United States' harshness in the area of criminal justice, in growing contrast to a relatively milder approach in continental Europe. See Whitman 2003.

119 Johnson attributes Japanese retention largely to the US occupation of that country, where unlike in Germany, "abolishing capital punishment was nowhere on this agenda..." Johnson 2006: 259. Capital punishment in contemporary Japan tends to be shrouded in secrecy, a legacy of the Occupation's policy of 'censored democracy' p. 260. On the culture aspects of the American commitment to the death penalty, see Garland 2002.

120 Of course it is difficult to know the exact extent of state executions in many highly repressive countries; in the Soviet Union for example that information was a state secret Puhar 2005, 59.

${ }^{121}$ Zimring 2003: 10.

122 This was the case in Poland, for example. See Fijalkowski 2005: 157.

123 Puhar 2005, 83.
} 
argument that can be made against the death penalty, ${ }^{124}$ broad swathes of democratic publics are likely to accept the utilitarian notion that the death penalty deters crime ${ }^{125}$ and to believe that it appropriately respects the interests of victims and/or their families for "closure.” 126 "Tough on crime” rhetoric can be used to deflect incipient concerns regarding the morality of capital punishment, and mobilize popular consent for the death penalty. ${ }^{127}$

\section{The Death Penalty in International Law}

The death penalty has only been addressed in international law since World War II. It was discussed by the Human Rights Commission while debating the contents of the Universal Declaration, but no clear consensus could be reached. Article 3 provides that "Everyone has the right to life, liberty and security of person" while Article 5 requires that "No one shall be subjected to torture or to cruel, inhuman or degrading treatment or punishment.”128 No specific mention is made of the death penalty. Negotiation of the ICCPR provided another opportunity to be explicit about banning the death penalty in international law. This time the opportunity was taken, but a clear compromise was struck. The Covenant reiterated an affirmative right to life. ${ }^{129}$ It also provided that for countries that had not already abolished the death penalty, that it should be used only for the most serious crimes, but that this provision should not be used to justify delay of abolition. ${ }^{130}$ An explicit ban was opposed by the United States as well as the majority of predominantly Muslim countries. ${ }^{131}$ While there may have been some assumption of an eventual ban by many countries, continuing disagreement led to compromise language.

In contrast to fair trial guarantees, which are rarely opposed in principle by any government, state opponents of the death penalty are often explicit in their opposition. The strongest opponents to the abolition of the death penalty in UN debates have been Singapore and Egypt, who have led the charge against several EU efforts to universalize and strengthen

\footnotetext{
124 Perry 2007: 37-51.

125 Palmer and Henderson 1998; Wynarczyk 1999. Studies that conclude that the death penalty deters crime include Ehrlich 1975; Wolpin 1978. Support for the death penalty as a deterrent to crime is also strong in (non-democratic) China, despite the lack of any government propaganda to influence public opinion. See Ho 2005: 280-81. There is also good evidence that the demand for capital punishment increase as the seriousness of the crime in the respondent's location increases. See Cameron 1993.

126 Dunér and Geurtsen 2002: 10.

127 Garland 2001.

128 Articles 3 and 5 of the UDHR, text at http://www.un.org/Overview/rights.html.

129 ICCPR, Article 6 para. 1.

130 ICCPR, Article 6 para. 2.

131 Wyman 1997. The only outright ban on the death penalty contained in the ICCPR is in the case of minors, against which the United States entered a reservation, and pregnant women (Article 6 para. 5).
} 
international law on the death penalty. ${ }^{132}$ Several governments have made clear reservations or declarations to the ICCPR, indicating their clear understanding that it does not prohibit the use of capital punishment. Both the United States' and China's reservations to the ICCPR, for example, explicitly exempt them from provisions regarding the death penalty. ${ }^{133}$ In debates before the United Nations, Sudan has claimed that "Capital punishment is a divine right of some religions. It is embodied in Islam and these views must be respected." ${ }^{134}$ While some scholars have claimed that the ban against the death penalty has hardened into a custom in international law, ${ }^{135}$ it seems unlikely that this view would be broadly accepted outside of Europe and possibly Latin America.

The countries of Europe were determined to proceed with law development against the death penalty, despite opposition from the United States and the Middle and Far East. Crucial in Europe was the reframing of the death penalty as a human rights issue rather than as an issue of criminal justice. After 30 years of domestic legal change effectively banning capital punishment at the national level, the most important regional legal change came with passage of the 1983 Protocol No. 6 of the European Convention on Human Rights. ${ }^{136}$ Like the multilateral optional protocol that was to follow, this regional accord banned the death penalty unequivocally, though allowing for reservations preserving the option for the most serious crimes during wartime. ${ }^{137} \mathrm{~A}$ year later, the UN Economic and Social Council adopted a resolution that acknowledged the gravity of the issue without broaching the question of a ban by adopting a resolution to protect the rights of persons facing the death penalty. ${ }^{138}$

The general prohibition in international law on executions came in the form of an optional protocol to the ICCPR. ${ }^{139}$ Adopted by the General Assembly in 1989, this instrument bans executions outright. ${ }^{140}$ Like European Protocol No. 6, this agreement abolishes the death

\footnotetext{
132 Bantekas and Hodgkinson 2000.

133 Albrecht 2000: 99.

134 This was a 1994 statement, as quoted by Hood 2001: 341.

135 Ohlin 2005.

136 Protocol No. 6 to the 1950 European Convention for the Protection of Human Rights and Fundamental Freedoms, E.T.S. 114, entered into force March 1, 1985. See text at http://www1.umn.edu/humanrts/euro/z25prot6.html.

137 Protocol No. 6, Articles 1 and 2.

138 Safeguards guaranteeing protection of the rights of those facing the death penalty Adopted by Economic and Social Council resolution 1984/50 of 25 May 1984 http://www.unhchr.ch/html/menu3/b/h_comp41.htm

${ }^{139}$ Second Optional Protocol to the International Covenant on Civil and Political Rights, aiming at the abolition of the death penalty Adopted and proclaimed by General Assembly resolution 44/128 of 15 December 1989. Text at http://www.unhchr.ch/html/menu3/b/a_opt2.htm.

140 Second Optional Protocol to the ICCPR, Article 1 para. 1.
} 
penalty in all situations including war, unless country specifies through reservation at the time of ratification. ${ }^{141}$ The Second Optional Protocol to the ICCPR is the clearest obligatory multilateral document to ban the death penalty under virtually all circumstances. The next section considers the extent to which countries have actually complied with their legal obligations in this area, by looking at actual patterns of death penalty abolition.

\section{Data and Methods}

If the ICCPR and most especially the Optional Protocol on the Death Penalty have had any influence on states practices, we should expect the propensity to remove the death penalty to correspond with ICCPR and OP ratification. Of all of the civil rights we have examined in this paper, we should expect the results to be the strongest: abolition is a public policy and execution is generally a public act taken by the central government in large part for its deterrence value. It is relatively easy to monitor cases of capital execution - at least in comparison with torture and the fairness of a criminal trial. ${ }^{142}$ We should expect compliance to be clearly associated with commitment to the ICCPR and its optional protocol once we have accounted for the factors that lead countries to ratify these agreements in the first place, as well as a host of alternative explanations (discussed below) for reliance on the death penalty itself.

The dependent variable in the first instance is whether or not the central government has the death penalty; the second is whether or not a state removes the death penalty within their jurisdiction. The latter is indicated by the first year capital punishment is banned. In both cases, I use a pooled time series for this test and two-stage least squares for whether or not the death penalty is in place, and for death penalty removal ${ }^{143}$ (endogenizing ICCPR and Optional Protocol ratification in both cases). I expect ratification to reduce the incidence of the death penalty (a negative coefficient) and increase the likelihood that the death penalty will be abolished (a positive coefficient).

Before proceeding, it is useful to note that the use of the death penalty is on the decline on average world wide. Figure 4 charts the upward trend of countries that have abolished the death penalty completely, the decrease in countries that have abolished it for ordinary crimes, and

${ }^{141}$ Second Optional Protocol to the ICCPR, Article 2 para 1. See discussion in Dunér and Geurtsen 2002: 7. They note very few countries make such a reservation upon ratification (p. 9).

${ }^{142}$ Use of the death penalty may however be correlated with violence, torture and extrajudicial killings. See Miethe, Lu, and Deibert 2005.

${ }^{143}$ A probit model would have been more appropriate here given the dichotomous nature of the data, but the full model could not converge with the proper range of controls as well as fixed effects, and so 2SLS was used. As a robustness check, I test whether or not a country uses the death penalty, looking at a single year (2000). The results support the general conclusions reported here. 
the nearly constant number of countries that retain the death penalty for extraordinary crimes (such as treason during wartime). The figure also shows the upward trend in the number of countries that have ratified the Second Optional Protocol to the ICCPR since 1989.

\section{[FIGURE 4 ABOUT HERE]}

The empirical problem is to estimate the influence that ratification has had on actual practices. In addition to endogenizing the treaty commitment itself, a battery of controls are included to reduce the chance that alternative explanations wash out the effect of making an international legal commitment. Because many theories of the death penalty view it as a mechanism of social control, and because ethnic diversity is sometimes construed as a threat to such control, one might expect the death penalty to be much more widespread in societies with a high degree of ethnic fractionalization. ${ }^{144}$

Domestic political conditions are also likely to be a major explanation. Although democracy per se is not an obvious correlate (as discussed above), I control for regime type and changes in regime type on the hypothesis that the trend to abolish the death penalty is a reflection of the waves of liberal reform sweeping much of the world generally. Previous research has noted that military governments are more likely to retain the death penalty, as are conservative or right wing governments, ${ }^{145}$ and so I control for military control of the government as well as government partisanship. At least in the United States, federalism is largely responsible for the retention of the death penalty; these tests control for the degree of decentralization of government in each case.

The security environment is also a likely contributor to the decision to impose or lift the death penalty. The option to make reservations allowing for the death penalty in wartime signals the importance states have given to issues of national security. I hypothesize that the death penalty is more likely to be retained in states facing civil or international wars. ${ }^{146}$ Some analysts

\footnotetext{
144 Existing research suggests that the death penalty is associated with societies in which dominant ethnic groups feel threatened by significant minorities or subordinate majority groups. See for example Ruddell 2005; Soss, Langbein, and Metelko 2003; Turrell 2004.

145 Research suggests that right-wing parties are much more likely to crack down on crime through greater imprisonment than are left wing parties, even controlling for rates of crime and unemployment Sutton 2000. In the US, more vigilant law enforcement is associated with Republican party governance. See Jacobs and Helms 1997. In the United States, states that have higher numbers of people identifying as republicans are more likely to legalizes the death penalty (Jacobs and Carmichael 2002.), and to impose it as well (Jacobs and Carmichael 2004.). On the history of the partisan fight in the British parliament, see Block and Hostettler 1997.

${ }^{146}$ Dunér and Geursten look at simple percentages and find that fewer countries experiencing recent war have ratified a death penalty protocol than those enjoying peace. Dunér and Geurtsen 2002: 12.
} 
have noted that capital punishment is an instrument of state consolidation. ${ }^{147}$ To account for this possibility, I include the logged years since each state's independence. The longer it has been since independence, the less the imperative to maintain capital punishment for purposes of consolidating state authority.

Finally, it is obvious the international environment has been important in fueling the abolition movement. ${ }^{148}$ The most important factor in this area has been the role that Europe has played in trying to persuade governments around the world that capital punishment violates basic human rights and ought to be banned. The Council of Europe has made elimination of the death penalty a requirement for joining the Council and a criterion of "democracy."149 The EU campaigns for universal abolition of the death penalty in all circumstances; in fact since 1998 abolition of the death penalty has been a formal condition of membership, and has clearly influenced the policies of some new member states, such as Estonia. ${ }^{150}$ By comparison, the InterAmerican regime - the only other region to have an explicit position toward the death penalty freezes current practices, but does not abolish capital punishment. ${ }^{151}$ I therefore include indicators that should reflect a country's anticipation of joining the Council of Europe (membership three years in the future), the density of regional death penalty states, and a dummy variable for Europe itself (East and West). If patterns of abolition are primarily due to European socialization (or pressure), these indicators should be associated with a reduction in the death penalty and increase in the probability of banning the practice.

Findings: The ICCPR, the Optional Protocol, and Abolition of the Death Penalty The results are displayed in Tables 4 and 5. The primary result is strong support for the proposition that countries that ratify the ICCPR and the Optional Protocol are clearly associated with abolition of the death penalty in their jurisdiction. In Table 4, it is clear that ratification of the Optional Protocol reduces the likelihood that a state will have the death penalty by anywhere from 7 to 11 percent. This is an effect that is estimated to be directly attributable to the Optional Protocol, net of the factors that led the government to ratify it in the first place, net of ICCPR ratification, and net of all of the control variables included in the various specifications. Moreover, ratification of the Optional Protocol is associated with anywhere from a 30 to 50 percent greater chance that a country will abolish the death penalty. Given that many countries

\footnotetext{
147 Turrell 2004.

148 Zimring 2003: 39.

149 Bantekas and Hodgkinson 2000: 23; Fawn 2001; Puhar 2005.

150 Puhar 2005, 103.

151 Some have therefore judged it “symbolic.” See Dunér and Geurtsen 2002: 7.
} 
abolish in anticipation of ratification, this is a significant impact. This is one area of human rights commitment in which governments commit and follow up with a very high probability.

Several other factors have a strong relationship with death penalty practices as well. Across all specifications, there is strong evidence that ethnic fractionalization is associated with maintenance of the death penalty. The presence of many ethnic groups makes is likely that a state will have the death penalty, and much less likely that it will be removed. The domestic political variables that one might have thought would be associated with the death penalty hardly contribute to the explanation at all, and when they do, they are not in the direction one would expect (military governments are slightly less likely according to table 4 to preside over the death penalty). As one would expect, the death penalty is much more likely to exist and much less likely to be removed in countries that have had recent civil war experience, although not necessarily embroiled in civil conflict at the moment.

As noted above, the ICCPR itself does not ban the death penalty. Ratification of the ICPR alone is associated with a much weaker effect on death penalty practices than is the Optional Protocol. In only one model - the one with domestic political controls - was there a convincing statistical relationship between ICCPR ratification alone and existence of the death penalty. Only in one model of death penalty repeal did ICCPR ratification have a statistically stronger relationship with repeal than did the Optional Protocol. In each of these cases, the substantive significance of the Optional Protocol far outweighs the substantive impact of ICCPR ratification. The substantive effect of the OP on repeal of the death penalty was between 4 to 7 times larger than for the main treaty. This evidence is consistent with a theory of international law that associates commitment with a serious effort to comply. In the case of capital punishment, characterized by centralized policies that are reasonably easy to monitor, states do not ratify until they are certain they will be willing and able to comply. Ratification matters in these cases, precisely because it is straightforward to monitor, observe and criticize potential violations.

\section{Conclusions}

The development of international human rights law has been one of the most significant projects of the last sixty years. Statesmen, activists, legal scholars, and organizations have committed a great deal of effort to fashioning a legal regime by which individuals might claim a broad array of civil rights vis-à-vis their own governments. Many have boldly labeled the central documents reflecting these efforts as "The International Bill of Rights" and have touted it as the 
closest thing the international community has to a global constitutional statement of the rights of the civil rights of human kind. There is little doubt that the Universal Declaration and the ICCPR represent normative aspirations of a good number of well-intentioned individuals, but it is also necessary to take stock of the effects of these documents, and ask, what have they contributed to the actual realization of the rights they proclaim?

This paper has been a modest step toward exploring and trying to answer this question. It has gone beyond claims that treaty ratification is largely symbolic, and taken seriously the idea that domestic rights demandeurs have strong incentives to use whatever tools are available to them - including international treaty commitments - to claims the rights these treaties express. One surprise has been that ratification has mattered at all to civil rights practices, given the prevailing assumption that such commitments are close to meaningless and largely unenforced by external actors. It is also surprising given the stringency of the models developed here. It is not easy to claim, given these analyses, that in broadening religious freedom, making trials fairer and abolishing the death penalty that governments are simply mimicking others, that this is just a residual consequence of the process of democratization, or that the government would have changed its behavior even in the absence of the treaty commitment. These claims do not ring true, because they are largely controlled for by the nature of the tests performed. The methods I use do not prove a causal relationship between treaty ratification and improved practices, but they do eliminate many alternative explanations that one might have initial thought would be a more powerful explanation of official civil rights choices. Nor do I claim that they treaty commitment is the only or even the most important reason for the improvements we do observe. The claim is rather that such commitments have made an important contribution to rights practices, and that scholars and practitioners have not to date been able or willing to recognize this contribution.

Why should treaty ratification matter? The mechanisms are potentially myriad, but one is especially plausible: treaty ratification matters because it stimulates domestic organization and mobilizes locals to claim the rights the treaty contains. We have seen that ICCPR ratification is followed by a burst of civil society organization, consistent with the idea that citizens view the post ratification period as a time to organize to demand the kinds of rights the treaty promises on paper. Of course, not all kinds of issues elicit identical kinds or degrees of domestic mobilization. This research shows that there is a real payoff to breaking out different kinds of "civil rights" and comparing the treaty impact across issue areas. This is important because the politics differ across these issue areas in ways relevant to the mechanisms of treaty compliance. Compare religious freedom with fair trials, for example. The domestic demands for compliance are likely to be much stronger for religious freedom than for fair trials. In many cases, religious 
freedom will be demanded by organized religious groups, who have the organizational capacity to press the government to allow them to worship and practice their religion freely. The primary demanduers of fair trials may not only be political opponents of the government, but also an unsavory array of criminals. Not only is it difficult for such groups to organize themselves, it is also often difficult to assemble a broad coalition for fair trials because this can be framed as being soft on crime. Unsurprisingly, ratification has a less convincing impact on fair trials. This does not mean, however, that a treaty commitment is meaningless where mobilization is weak. It may mean that other means must be found to enforce compliance. In Egypt, for example, the high court has used the ICCPR to craft rulings that improve the fairness of trials. ${ }^{152}$

One of the most striking results is the evidence of stronger treaty effects in countries experiencing regime instability or transition. This was found to be the case with respect both to religious freedom and fair trials. The theoretical discussion provided a good reason to suspect that treaty ratification would have the least impact in stable democracies (where rights are already very well protected) and in stable autocracies (where people anticipate harsh repression were they ever to demand treaty compliance). The evidence analyzed here is quite consistent with these expectations. With respect to religious freedom, the ICCPR has apparently had practically no impact in stable democracies or autocracies, but has had a positive impact in countries with some prospect of or experience with moderately responsive government. The evidence was weaker with respect to fair trials, but the basic pattern was similar: much more convincing positive ratification effects in the transition countries than in the stable extremes.

Death penalty compliance contrasts with both fair trials and religious freedom. For starters, governments have often been out ahead of their publics on the issue of death penalty abolition. As I have discussed above, in countries from the United Kingdom to Estonia to Poland, European elites have tended to lead their mass publics toward abolition. Capital punishment also contrasts with other forms of government repression in that it is centrally carried out in a publicly authorized fashion. As a result it is easy to monitor - much easier than most other government rights practices, including not only fair trials, but also torture, the use of child soldiers, or a range of other rights violations that are carried out in a more decentralized fashion and are extremely difficult to observe The ability of other governments, domestic governmental officials, groups and citizens to monitor capital punishment all make this an especially crucial area for government to ratify a binding obligation only if they are committed to compliance. The strong positive association between ratification and abolition of the death penalty support this interpretation.

152 See for example Sharif 2000. 
These results suggest a modest but important conclusion: international treaty commitments quite likely have made a positive contribution to civil rights practices in many countries around the world. Of course, ratification of the ICCPR does not guarantee good practices. It certainly cannot overcome the stresses of a conflict ridden polity governed by a succession of despots. It may not even be as important as the examples (good and bad) provided by other governments in the region. But ratification does seem to support civil rights improvements on the margins. It does this most consistently where people have both the motive and the means to mobilize to demand compliance and where the practice in question can be monitored at reasonable cost. This finding contrast with those of previous scholars, who have viewed treaty commitments as cheap opportunities to score public relations points with few risks that they will be expected to improve the behaviors the treaty regulates. ${ }^{153}$ The evidence reviewed here indicates the case for mere symbolic ratification is far from open and shut. Rather, it is consistent with a theory that views ratification as a political opportunity - depending on the anticipated costs - to mobilize to demand civil rights guarantees from ones own government.

\footnotetext{
153 Hathaway 2002; Keith 1999.
} 
Figures 1A and 1B:

\section{The Expected Value of Mobilization:}

Expected Value of Mobilization $=($ value of succeeding $) \times$ (probability of success $)$

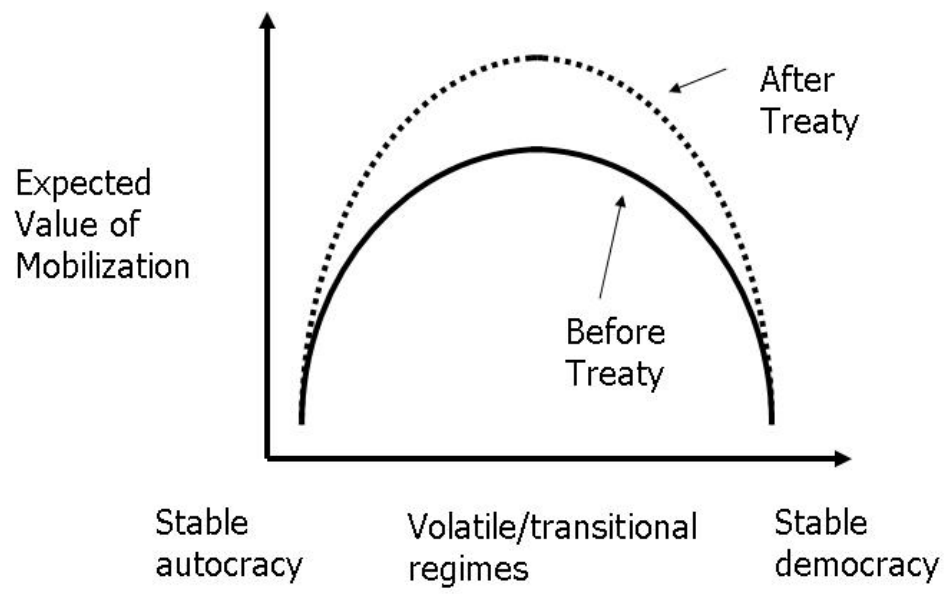

\section{How Treaties Mobilize Demands}

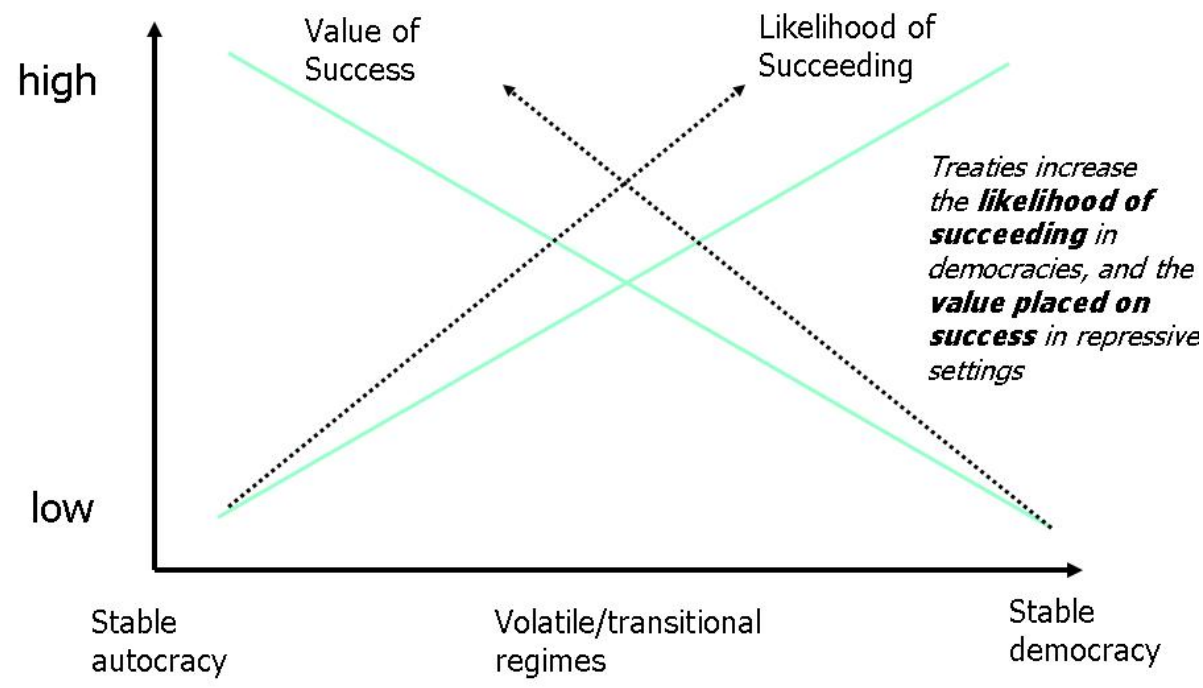


Table 1:

Effect of ICCPR ratification on local memberships in international non-governmental organizations

Dependent Variable: logged INGO memberships

OLS regression model

\begin{tabular}{|c|c|c|}
\hline & $\begin{array}{c}\text { Model 1: } \\
\text { (no fixed effects) }\end{array}$ & $\begin{array}{c}\text { Model 2: } \\
\text { Country Fixed Effects }\end{array}$ \\
\hline Logged INGO memberships, t-1 & $\begin{array}{l}.776^{* * *} \\
(\mathrm{p}=.000)\end{array}$ & -- \\
\hline ICCPR ratification, t-1 & $\begin{array}{l}.054^{* * * *} \\
(\mathrm{p}=.000)\end{array}$ & $\begin{array}{c}-.044 \\
(p=.155)\end{array}$ \\
\hline ICCPR ratification, $\mathrm{t}-2$ & -- & $\begin{array}{c}.011 \\
(p=.592)\end{array}$ \\
\hline ICCPR ratification, t-3 & -- & $\begin{array}{c}.033^{* *} \\
(\mathrm{p}=.030)\end{array}$ \\
\hline ICCPR ratification, $\mathrm{t}-4$ & -- & $\begin{array}{l}.034 * * * \\
(\mathrm{p}=.010)\end{array}$ \\
\hline ICCPR ratification, t-5 & -- & $\begin{array}{c}-.027 \\
(p=.175)\end{array}$ \\
\hline $\begin{array}{l}\text { Overseas development } \\
\text { assistance/GDP, t-1 }\end{array}$ & $\begin{array}{c}-.027 \\
(p=.488)\end{array}$ & $\begin{array}{l}.488 * * * \\
(\mathrm{p}=.001)\end{array}$ \\
\hline Logged total population, t-1 & $\begin{array}{l}.075^{* * *} \\
(\mathrm{p}=.000)\end{array}$ & $\begin{array}{c}.528 * * \\
(\mathrm{p}=.022)\end{array}$ \\
\hline Logged GDP/capita, t-1 & $\begin{array}{l}.072 * * * \\
(\mathrm{p}=.000)\end{array}$ & $\begin{array}{c}.135 \\
(p=.180)\end{array}$ \\
\hline Change in civil liberties, t-1 & -- & $\begin{array}{c}.007 \\
(p=.408)\end{array}$ \\
\hline Civil liberties, t-1 & $\begin{array}{l}.023^{* * *} \\
(\mathrm{p}=.000)\end{array}$ & \\
\hline Year trend & $\begin{array}{l}.005^{* * *} \\
(\mathrm{p}=.000)\end{array}$ & $\begin{array}{l}.042^{* * *} \\
(\mathrm{p}=.000)\end{array}$ \\
\hline Constant & $\begin{array}{c}-10.07 * * * \\
(\mathrm{p}=.000)\end{array}$ & \\
\hline Number of countries & 173 & 173 \\
\hline Number of Observations & 3646 & 3757 \\
\hline R-squared & .975 & .218 \\
\hline
\end{tabular}

$*=$ significant at .10 level $\quad * *=$ significant at .05 level $* * *=$ significant at .01 level

Note: country fixed effects included in Model 2 but not reported here. Because of the fixed effect, the lagged dependent variable (which functions as a "baseline" for change) is omitted.

Robust standard errors, clustering on country.

While inclusion of a time trend does not disturb these results, year fixed effects increase the standard errors on ICCPR ratification. 
Figure 2:

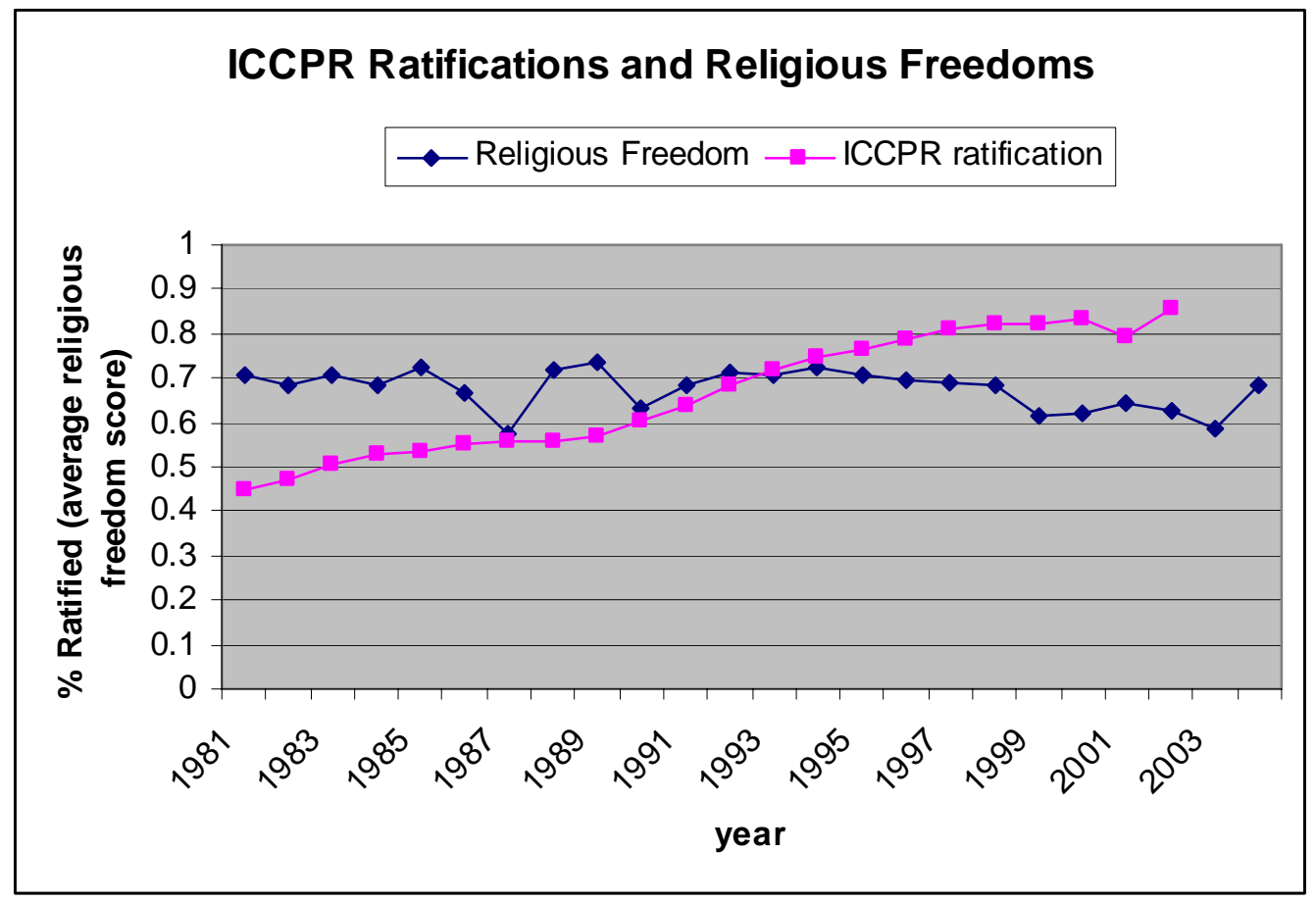


Table 2:

The ICCPR and Freedom of Religion (Dependent Variable: Religious Freedom)

Two-staged instrumental regression (endogenous: ICCPR ratification)

\begin{tabular}{|c|c|c|c|c|c|}
\hline & Model 1: & Model 2: & $\begin{array}{l}\text { Model 3: } \\
\text { transition } \\
\text { countries } \\
\text { only }\end{array}$ & $\begin{array}{c}\text { Model 4: } \\
\text { stable } \\
\text { democracies } \\
\text { only: }\end{array}$ & $\begin{array}{c}\text { Model 5: } \\
\text { stable } \\
\text { autocracies } \\
\text { only: }\end{array}$ \\
\hline $\begin{array}{l}\text { ICCPR obligation } \\
\text { (lagged } 5 \text { years) }\end{array}$ & $\begin{array}{c}.080^{*} \\
(\mathrm{p}=.055)\end{array}$ & $\begin{array}{c}.073^{*} \\
(\mathrm{p}=.089)\end{array}$ & $\begin{array}{c}.111^{* *} \\
(\mathrm{p}=.018)\end{array}$ & $\begin{array}{c}-.023 \\
(p=.165)\end{array}$ & $\begin{array}{c}.081 \\
(p=.402)\end{array}$ \\
\hline $\begin{array}{l}\text { State religion, } 1970- \\
2000\end{array}$ & $\begin{array}{l}.600 * * * \\
(\mathrm{p}=.052)\end{array}$ & $\begin{array}{l}.749 * * * \\
(\mathrm{p}=.000)\end{array}$ & -- & -- & $\begin{array}{c}-.614 \\
(p=.179)\end{array}$ \\
\hline $\begin{array}{c}\text { Establishing states, } \\
1970-2000\end{array}$ & $\begin{array}{c}-.033^{*} \\
(\mathrm{p}=.092)\end{array}$ & $\begin{array}{l}-.305 * * * \\
(\mathrm{p}=.009)\end{array}$ & $\begin{array}{l}-.709 * * * \\
(\mathrm{p}=.000)\end{array}$ & $\begin{array}{c}-.091 \\
(p=.329)\end{array}$ & $\begin{array}{c}.787 * * \\
(\mathrm{p}=.012)\end{array}$ \\
\hline $\begin{array}{c}\text { Disestablishing states, } \\
1970-2000 \\
\end{array}$ & $\begin{array}{l}-.518 * * * \\
(\mathrm{p}=.001)\end{array}$ & $\begin{array}{l}-.416 * * \\
(p=.016)\end{array}$ & $\begin{array}{l}.056 * * * \\
(\mathrm{p}=.000)\end{array}$ & $\begin{array}{c}.321 \\
(p=.304)\end{array}$ & $\begin{array}{c}.930 * \\
(p=.074)\end{array}$ \\
\hline Religious freedom, t-1 & $\begin{array}{l}.466^{* * *} \\
(\mathrm{p}=.000)\end{array}$ & $\begin{array}{l}.464 * * * \\
(\mathrm{p}=.000)\end{array}$ & $\begin{array}{l}.471^{* * *} \\
(\mathrm{p}=.000)\end{array}$ & $\begin{array}{l}.426 * * * \\
(\mathrm{p}=.000)\end{array}$ & $\begin{array}{l}.456 * * * \\
(\mathrm{p}=.000) \\
\end{array}$ \\
\hline $\begin{array}{c}\text { Religious } \\
\text { fractionalization } \\
\end{array}$ & $\begin{array}{l}-.0002^{* * *} \\
(\mathrm{p}=.000)\end{array}$ & $\begin{array}{l}-.0002^{* * *} \\
(\mathrm{p}=.000)\end{array}$ & $\begin{array}{l}.597 * * * \\
(\mathrm{p}=.010)\end{array}$ & -- & $\begin{array}{c}-.00006^{* * * *} \\
(\mathrm{p}=.000)\end{array}$ \\
\hline $\begin{array}{c}\text { Overseas development } \\
\text { aid, t-1 } \\
\end{array}$ & $\begin{array}{l}.476^{* * *} \\
(\mathrm{p}=.004)\end{array}$ & $\begin{array}{l}.480 * * * \\
(\mathrm{p}=.006)\end{array}$ & $\begin{array}{c}.311^{*} \\
(p=.091)\end{array}$ & $\begin{array}{c}.669 \\
(\mathrm{p}=.351)\end{array}$ & $\begin{array}{c}.541^{* *} \\
(\mathrm{p}=.018)\end{array}$ \\
\hline Logged GDP/capita & $\begin{array}{c}-.097 * \\
(p=.052)\end{array}$ & $\begin{array}{c}-.093^{*} \\
(\mathrm{p}=.090)\end{array}$ & $\begin{array}{c}-.126^{*} \\
(\mathrm{p}=.106)\end{array}$ & $\begin{array}{c}-.027 \\
(p=.666)\end{array}$ & $\begin{array}{c}-.155^{*} \\
(\mathrm{p}=.092)\end{array}$ \\
\hline Islam & $\begin{array}{l}-.032 * * * \\
(\mathrm{p}=.015)\end{array}$ & $\begin{array}{c}-.18 \\
(p=.306)\end{array}$ & $\begin{array}{c}.149 \\
(p=.122)\end{array}$ & -- & $\begin{array}{l}-.055 * * \\
(\mathrm{p}=.030)\end{array}$ \\
\hline Catholic & $\begin{array}{l}.454 * * * \\
(\mathrm{p}=.000)\end{array}$ & $\begin{array}{l}.463 * * * \\
(\mathrm{p}=.000)\end{array}$ & $\begin{array}{c}-.382 * \\
(p=.985)\end{array}$ & $\begin{array}{c}-.073 \\
(p=.405)\end{array}$ & $\begin{array}{l}.856 * * * \\
(p=.008)\end{array}$ \\
\hline Protestant & $\begin{array}{l}.108^{* * *} \\
(\mathrm{p}=.000)\end{array}$ & $\begin{array}{c}.241 * \\
(p=.055)\end{array}$ & $\begin{array}{c}-.061 \\
(p=.274)\end{array}$ & $\begin{array}{c}.165 \\
(p=.483)\end{array}$ & $\begin{array}{c}1.27 * * \\
(p=.013)\end{array}$ \\
\hline Democracy & -- & $\begin{array}{c}.002 \\
(p=.336)\end{array}$ & & -- & -- \\
\hline GDP growth & -- & $\begin{array}{c}.0004 \\
(p=.760)\end{array}$ & -- & -- & -- \\
\hline Trade openness & -- & $\begin{array}{c}-.0005 \\
(p=.336)\end{array}$ & -- & -- & -- \\
\hline Civil war & -- & $\begin{array}{c}.023 \\
(p=.527)\end{array}$ & -- & -- & -- \\
\hline Interstate war & -- & $\begin{array}{c}.019 \\
(p=.620)\end{array}$ & -- & -- & -- \\
\hline Country fixed effects? & yes & yes & yes & yes & yes \\
\hline Year fixed effects? & yes & yes & yes & yes & yes \\
\hline \# of countries & & & 55 & 32 & 59 \\
\hline \# of observations & 2691 & 2556 & 1022 & 661 & 1038 \\
\hline R-squared & .700 & .702 & .701 & .343 & .644 \\
\hline
\end{tabular}

Instruments: All explanatory variables, plus ratification procedures, common law tradition, regional

ICCPR density, a counting vector of years without ICCPR ratification, three cubic splines, and a year trend. 
Figure 3:

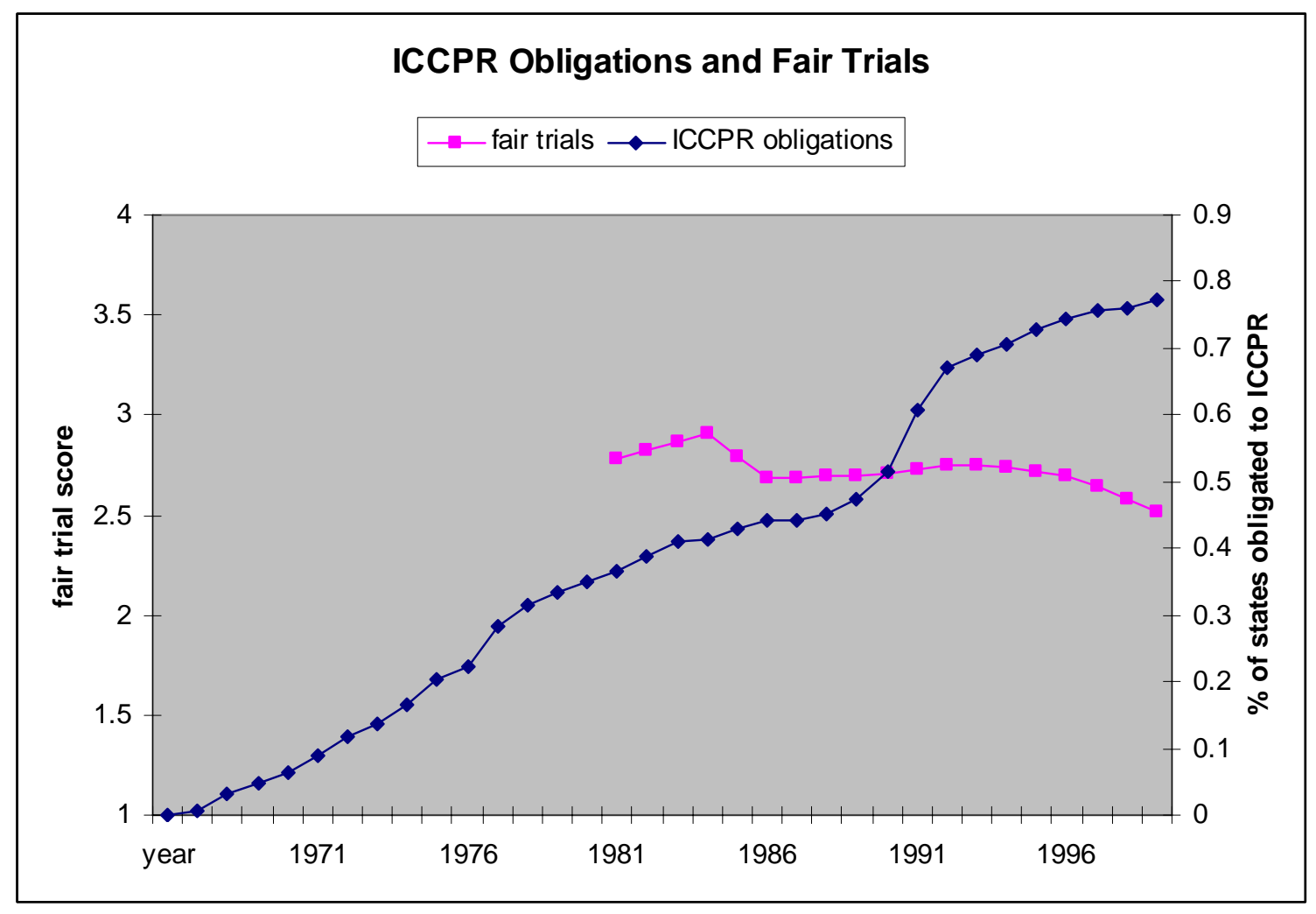

Source: Fair trials score: Hathaway 2002 (undated, interpolated, and inverted so that high values represent better practices). 
Table 3

Effects of an ICCPR Commitment on Fair Trials

Dependent Variable: Fair Trial Practices

Two-staged instrumental regression (endogenous: ICCPR ratification)

\begin{tabular}{|c|c|c|c|c|c|c|}
\hline $\begin{array}{l}\text { Explanatory } \\
\text { Variables: }\end{array}$ & $\begin{array}{l}\text { All } \\
\text { countries }\end{array}$ & $\begin{array}{l}\text { Trans. } \\
\text { only }\end{array}$ & $\begin{array}{l}\text { Trans. } \\
\text { Only, with } \\
\text { controls }\end{array}$ & $\begin{array}{l}\text { Never } \\
\text { democratic } \\
\text { only }\end{array}$ & $\begin{array}{l}\text { Stable } \\
\text { democraci } \\
\text { es only }\end{array}$ & $\begin{array}{l}\text { Trans., } \\
\text { ICCPR } 5 \\
\text { year lag }\end{array}$ \\
\hline $\begin{array}{l}\text { ICCPR } \\
\text { commitment }\end{array}$ & $\begin{array}{l}.168 \\
(p=.175)\end{array}$ & $\begin{array}{l}.314^{*} \\
(\mathrm{p}=.086)\end{array}$ & $\begin{array}{l}.348^{*} \\
(p=.087)\end{array}$ & $\begin{array}{l}.094 \\
(p=.674)\end{array}$ & $\begin{array}{l}-.076 \\
(p=.509)\end{array}$ & $\begin{array}{l}.055 \\
(p=.763)\end{array}$ \\
\hline Fair trials (t-3) & $\begin{array}{l}0.163 * * * \\
(\mathrm{p}=.002)\end{array}$ & $\begin{array}{l}.152^{* *} \\
(\mathrm{p}=.024)\end{array}$ & $\begin{array}{l}.148 * * \\
(\mathrm{p}=.047)\end{array}$ & $\begin{array}{l}.110 \\
(p=.125)\end{array}$ & $\begin{array}{l}.206 \\
(p=.220)\end{array}$ & $\begin{array}{l}.174^{* *} \\
(\mathrm{p}=.027)\end{array}$ \\
\hline $\begin{array}{l}\text { Regional fair } \\
\text { trial average (t- } \\
\text { 2) }\end{array}$ & $\begin{array}{l}.163 * * * \\
(\mathrm{p}=.001)\end{array}$ & $\begin{array}{l}.909 * * * \\
(\mathrm{p}=.000)\end{array}$ & $\begin{array}{l}1.00 * * * \\
(\mathrm{p}=.000)\end{array}$ & $\begin{array}{l}.647^{*} \\
(p=.054)\end{array}$ & $\begin{array}{l}.362 * * * \\
(\mathrm{p}=.001)\end{array}$ & $\begin{array}{l}1.01 * * * \\
(\mathrm{p}=.000)\end{array}$ \\
\hline $\begin{array}{l}\text { Democracy } \\
\text { (level) }\end{array}$ & $\begin{array}{l}-.004) \\
(p=.635)\end{array}$ & -- & $\begin{array}{l}-.004 \\
(p=.70)\end{array}$ & $\begin{array}{l}-.008 \\
(p=.570)\end{array}$ & $\begin{array}{l}.278^{* * *} \\
(\mathrm{p}=.001)\end{array}$ & $\begin{array}{l}.0003 \\
(p=.978)\end{array}$ \\
\hline $\begin{array}{l}\text { Democratic } \\
\text { change }\end{array}$ & $\begin{array}{l}-0.019 * * * \\
(\mathrm{p}=.006)\end{array}$ & $\begin{array}{l}-.017 * * \\
(\mathrm{p}=.019)\end{array}$ & $\begin{array}{l}-.020 * * \\
(\mathrm{p}=.017)\end{array}$ & $\begin{array}{l}-.014 \\
(\mathrm{p}=.211)\end{array}$ & $\begin{array}{l}.134 * \\
(p=.05)\end{array}$ & $\begin{array}{l}-.019 * * \\
(\mathrm{p}=.018)\end{array}$ \\
\hline $\begin{array}{l}\text { Military } \\
\text { government }\end{array}$ & $\begin{array}{l}-.144 \\
(p=.148)\end{array}$ & $\begin{array}{l}-.267 * * \\
(\mathrm{p}=.020)\end{array}$ & $\begin{array}{l}-.243^{*} \\
(\mathrm{p}=.052)\end{array}$ & $\begin{array}{l}.054 \\
(p=.650)\end{array}$ & -- & $\begin{array}{l}-.236^{*} \\
(\mathrm{p}=.067)\end{array}$ \\
\hline $\begin{array}{l}\text { Truth } \\
\text { commission }\end{array}$ & $\begin{array}{l}.436^{* *} \\
(\mathrm{p}=.025)\end{array}$ & -- & $\begin{array}{l}.349 * \\
(\mathrm{p}=.083)\end{array}$ & $\begin{array}{l}.105 \\
(p=.558)\end{array}$ & $\begin{array}{l}.299 \\
(p=.263)\end{array}$ & $\begin{array}{l}.360 \\
(p=.116)\end{array}$ \\
\hline Criminal trials & $\begin{array}{l}.023 \\
(p=.814)\end{array}$ & -- & $\begin{array}{l}.038 \\
(p=.717)\end{array}$ & $\begin{array}{l}.079 \\
(p=.649)\end{array}$ & $\begin{array}{l}.223 * * \\
(\mathrm{p}=.018)\end{array}$ & $\begin{array}{l}.037 \\
(p=.734)\end{array}$ \\
\hline $\begin{array}{l}\text { Logged Total } \\
\text { fractionalization }\end{array}$ & $\begin{array}{l}.440^{*} \\
(\mathrm{p}=.089)\end{array}$ & -- & $\begin{array}{l}.061 \\
(p=.932)\end{array}$ & $\begin{array}{l}-.097 \\
(\mathrm{p}=.837)\end{array}$ & $\begin{array}{l}3.97 * * * \\
(\mathrm{p}=.001)\end{array}$ & $\begin{array}{l}-.243 \\
(p=.731)\end{array}$ \\
\hline $\begin{array}{l}\text { Logged } \\
\text { GDP/capita }\end{array}$ & $\begin{array}{l}-.235 \\
(\mathrm{p}=.354)\end{array}$ & -- & $\begin{array}{l}.111 \\
(\mathrm{p}=.811)\end{array}$ & $\begin{array}{l}-.598^{*} \\
(\mathrm{p}=.069)\end{array}$ & $\begin{array}{l}-.386 \\
(p=.217)\end{array}$ & $\begin{array}{l}.169 \\
(p=.731)\end{array}$ \\
\hline $\begin{array}{l}\text { Logged } \\
\text { population }\end{array}$ & $\begin{array}{l}-.845^{*} \\
(\mathrm{p}=.055)\end{array}$ & -- & $\begin{array}{l}.019 \\
(p=.983)\end{array}$ & $\begin{array}{l}-.189 \\
(p=.884)\end{array}$ & $\begin{array}{l}-1.92 * * * \\
(p=.001)\end{array}$ & $\begin{array}{l}.413 \\
(p=.648)\end{array}$ \\
\hline $\begin{array}{l}\text { Overseas } \\
\text { development } \\
\text { assistance/GDP }\end{array}$ & $\begin{array}{l}.372 \\
(p=.600)\end{array}$ & -- & $\begin{array}{l}1.35 * \\
(p=.096)\end{array}$ & $\begin{array}{l}-.045 \\
(p=.962)\end{array}$ & $\begin{array}{l}-10.32 * * * \\
(\mathrm{p}=.001)\end{array}$ & $\begin{array}{l}1.37 * \\
(p=.085)\end{array}$ \\
\hline Civil war & $\begin{array}{l}-.207 * * \\
(\mathrm{p}=.044)\end{array}$ & -- & $\begin{array}{l}.006 \\
(p=.960)\end{array}$ & $\begin{array}{l}-.237 * \\
(p=.065)\end{array}$ & $\begin{array}{l}-1.04 * * * \\
(\mathrm{p}=.000)\end{array}$ & $\begin{array}{l}.038 \\
(p=.757)\end{array}$ \\
\hline Interstate war & $\begin{array}{l}-.255^{* *} \\
(\mathrm{p}=.034)\end{array}$ & -- & $\begin{array}{l}-.021 \\
(\mathrm{p}=.809)\end{array}$ & $\begin{array}{l}-.521 * * * \\
(\mathrm{p}=.000)\end{array}$ & $\begin{array}{l}.090^{*} \\
(\mathrm{p}=.097)\end{array}$ & $\begin{array}{l}-.005 \\
(p=.953)\end{array}$ \\
\hline Rule of Law & $\begin{array}{l}1.83^{* *} \\
(\mathrm{p}=.020)\end{array}$ & -- & $\begin{array}{l}-.631 \\
(\mathrm{p}=.643)\end{array}$ & $\begin{array}{l}.340 \\
(p=.557)\end{array}$ & $\begin{array}{l}.497 \\
(p=.158)\end{array}$ & $\begin{array}{l}-.217 \\
(\mathrm{p}=.871)\end{array}$ \\
\hline $\begin{array}{l}\text { Country fixed } \\
\text { Effects }\end{array}$ & yes & yes & yes & yes & yes & yes \\
\hline Yr. fixed effects & yes & yes & yes & yes & yes & yes \\
\hline Observations & 1890 & 746 & 684 & 756 & 434 & 684 \\
\hline \# of countries & 140 & 55 & 51 & 59 & 28 & 51 \\
\hline R-squared & 0.767 & 0.724 & .725 & 0.580 & 0.881 & 0.715 \\
\hline
\end{tabular}

Results of Two-Stages Least Squares regression; Instrumented: ICCPR obligation. Instruments:

All explanatory variables above, plus ratification procedures, common law legal tradition, regional ICCPR obligation density, a counting vector of years without ICCPR ratification, three cubic splines, and a year time trend. 
Robust p values in parentheses; * significant at $10 \%$; ** significant at $5 \%$; *** significant at $1 \%$ 
Figure 4:

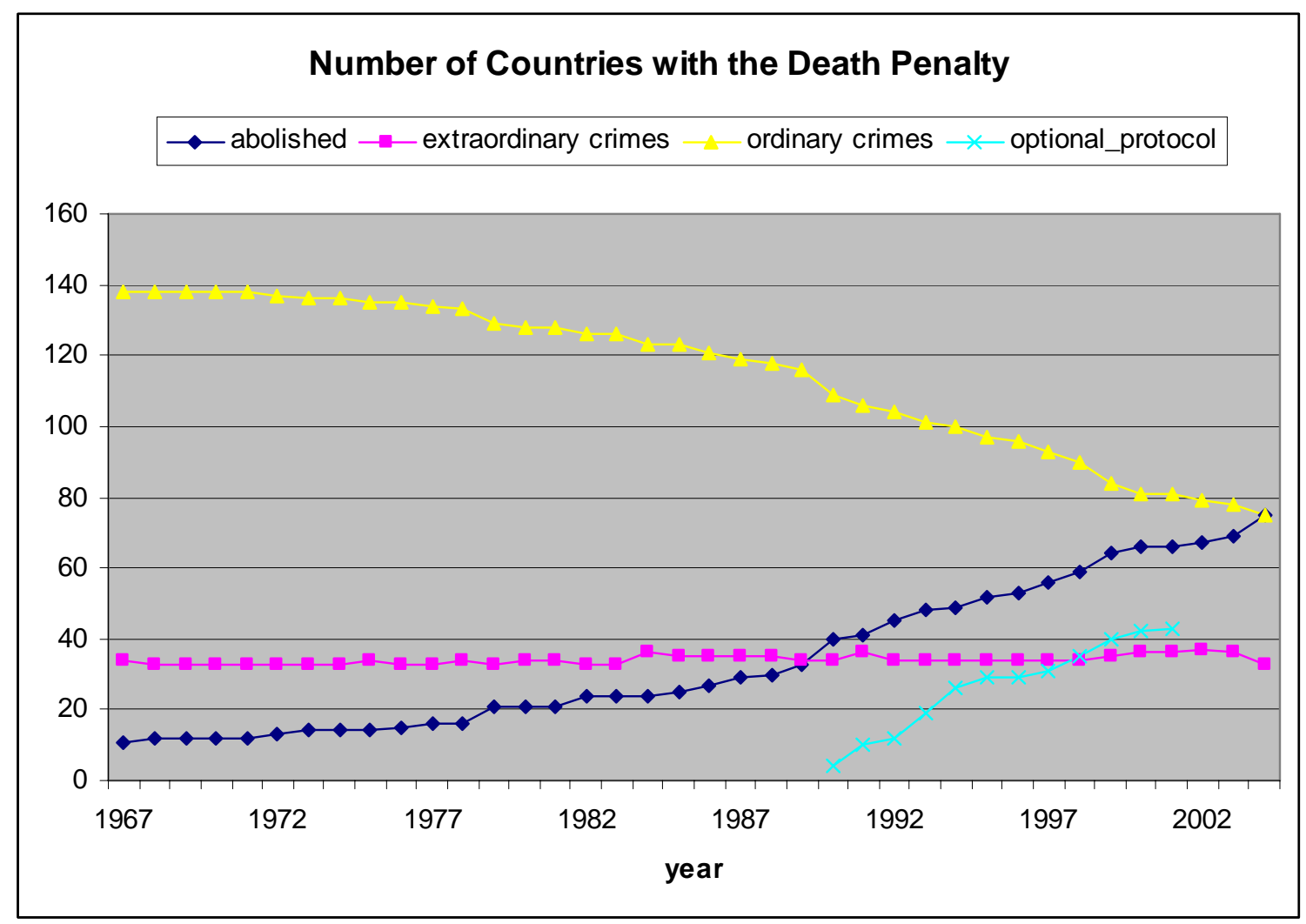

Source: Amnesty International: http://web.amnesty.org/pages/deathpenalty-countries-eng 
Table 4: ICCPR, the Optional Protocol, and the Death Penalty Instrumental variable regression model Dependent variable: De jure death penalty

\begin{tabular}{|c|c|c|c|c|}
\hline & $\begin{array}{l}\text { Model 1: } \\
\text { Basic: }\end{array}$ & $\begin{array}{l}\text { Model } 2 \\
\text { Domestic } \\
\text { Political } \\
\text { Controls: }\end{array}$ & $\begin{array}{l}\text { Model 3: } \\
\text { Security } \\
\text { controls: }\end{array}$ & $\begin{array}{l}\text { Model } 4 \\
\text { Regional } \\
\text { influences }\end{array}$ \\
\hline $\begin{array}{l}\text { ICCPR } \\
\text { ratification }\end{array}$ & $\begin{array}{l}-.036 \\
(\mathrm{p}=.456)\end{array}$ & $\begin{array}{l}-.082 * * * \\
(\mathrm{p}=.008)\end{array}$ & $\begin{array}{l}-.081 \\
(p=.157)\end{array}$ & $\begin{array}{l}-.018 \\
(p=.741)\end{array}$ \\
\hline $\begin{array}{l}\text { Optional } \\
\text { Protocol } \\
\text { ratification }\end{array}$ & $\begin{array}{l}-.09 * * * \\
(\mathrm{p}=.010)\end{array}$ & $\begin{array}{l}-.112 * * \\
(\mathrm{p}=.027)\end{array}$ & $\begin{array}{l}-.100 * * * \\
(p=.008)\end{array}$ & $\begin{array}{l}-.073^{*} \\
(\mathrm{p}=.096)\end{array}$ \\
\hline $\begin{array}{l}\text { Death penalty } \\
\text { (t-1) }\end{array}$ & $\begin{array}{l}.853^{* * *} \\
(\mathrm{p}=.000)\end{array}$ & $\begin{array}{l}.817^{* * *} \\
(\mathrm{p}=.000)\end{array}$ & $\begin{array}{l}.850^{* * *} \\
(p=.000)\end{array}$ & $\begin{array}{l}.861^{* * *} \\
(\mathrm{p}=.000)\end{array}$ \\
\hline $\begin{array}{l}\text { Years since last } \\
\text { execution }\end{array}$ & $\begin{array}{l}.040^{* * *} \\
(\mathrm{p}=.005)\end{array}$ & $\begin{array}{l}.048^{* * *} \\
(p=.008)\end{array}$ & $\begin{array}{l}.030^{* *} \\
(\mathrm{p}=.019)\end{array}$ & $\begin{array}{l}.039 * * * \\
(p=.004)\end{array}$ \\
\hline $\begin{array}{l}\text { Ethnic } \\
\text { Fractionalization }\end{array}$ & $\begin{array}{l}.141^{* *} \\
(\mathrm{p}=.011)\end{array}$ & $\begin{array}{l}.009 \\
(p=.576)\end{array}$ & $\begin{array}{l}.071^{* * *} \\
(\mathrm{p}=.008)\end{array}$ & $\begin{array}{l}-.026 \\
(p=.517) \\
\end{array}$ \\
\hline $\begin{array}{l}\text { Trade as GDP } \\
\text { share }\end{array}$ & $\begin{array}{l}-.0002 \\
(p=.117)\end{array}$ & $\begin{array}{l}-.0002 \\
(p=.151)\end{array}$ & $\begin{array}{l}-.00007 \\
(p=.515)\end{array}$ & $\begin{array}{l}-.0002 \\
(p=.209)\end{array}$ \\
\hline Democracy & -- & $\begin{array}{l}.0007 \\
(p=.454)\end{array}$ & -- & \\
\hline $\begin{array}{l}\text { Yearly change in } \\
\text { democracy }\end{array}$ & -- & $\begin{array}{l}.0004 \\
(p=.574)\end{array}$ & -- & \\
\hline $\begin{array}{l}\text { Military } \\
\text { government }\end{array}$ & -- & $\begin{array}{l}-.017^{*} \\
(p=.090)\end{array}$ & -- & \\
\hline Federalism & -- & $\begin{array}{l}-.003 \\
(p=.423)\end{array}$ & -- & \\
\hline Left government & -- & $\begin{array}{l}-.014 \\
(p=.205)\end{array}$ & -- & \\
\hline Civil war & -- & -- & $\begin{array}{l}-.007 \\
(p=.456)\end{array}$ & \\
\hline $\begin{array}{l}\text { Civil war } \\
\text { experience }\end{array}$ & & & $\begin{array}{l}.090^{* * *} \\
(\mathrm{p}=.006)\end{array}$ & \\
\hline Interstate war & -- & -- & $\begin{array}{l}.0004 \\
(p=.930)\end{array}$ & \\
\hline $\begin{array}{l}\text { Logged yrs since } \\
\text { independence }\end{array}$ & -- & -- & $\begin{array}{l}.002 \\
(p=.767)\end{array}$ & \\
\hline $\begin{array}{l}\text { Membership in } \\
\text { Council of } \\
\text { Europe }(\mathrm{t}+3)\end{array}$ & -- & -- & -- & $\begin{array}{l}-.002 \\
(p=.938)\end{array}$ \\
\hline $\begin{array}{l}\text { Regional death } \\
\text { penalty density } \\
\text { (t-1) }\end{array}$ & -- & -- & -- & $\begin{array}{l}.039 \\
(p=.312)\end{array}$ \\
\hline Europe & & & & $\begin{array}{l}.0007 \\
(p=.992)\end{array}$ \\
\hline Islam & & & & -.035 \\
\hline
\end{tabular}




\begin{tabular}{|l|l|l|l|l|}
\hline & & & & $(\mathrm{p}=.559)$ \\
\hline $\begin{array}{l}\text { Country fixed } \\
\text { effects? }\end{array}$ & yes & yes & yes & yes \\
\hline $\begin{array}{l}\text { Year fixed } \\
\text { effects? }\end{array}$ & yes & yes & yes & yes \\
\hline \# of observations & 4598 & 3033 & 4444 & 4598 \\
\hline$\#$ of countries & 170 & 149 & 169 & 170 \\
\hline $\mathrm{R}^{2}$ & .94 & .94 & .95 & .94 \\
\hline
\end{tabular}

$*=$ significant at .10 level $* *=$ significant at .05 level $* * *=$ significant at .01 level 
Table 5:

Death Penalty Abolition

Instrumental variable regression model

Dependent variable first year of Death Penalty Abolition

\begin{tabular}{|c|c|c|c|c|c|}
\hline & $\begin{array}{l}\text { Model 1: } \\
\text { Basic: }\end{array}$ & $\begin{array}{l}\text { Model } 2 \\
\text { Domestic } \\
\text { Political } \\
\text { Controls: }\end{array}$ & $\begin{array}{l}\text { Model 3: } \\
\text { Security } \\
\text { controls: }\end{array}$ & $\begin{array}{l}\text { Model } 4 \\
\text { Regional } \\
\text { influences }\end{array}$ & $\begin{array}{l}\text { Model } 5 \\
\text { full set of } \\
\text { controls }\end{array}$ \\
\hline $\begin{array}{l}\text { ICCPR } \\
\text { ratification }\end{array}$ & $\begin{array}{l}.078 \\
(p=.181)\end{array}$ & $\begin{array}{l}.065 \\
(p=.195)\end{array}$ & $\begin{array}{l}.114 \\
(p=.127)\end{array}$ & $\begin{array}{l}.080 \\
(p=.180)\end{array}$ & $\begin{array}{l}.084^{* *} \\
(\mathrm{p}=.050)\end{array}$ \\
\hline $\begin{array}{l}\text { Optional } \\
\text { Protocol } \\
\text { ratification }\end{array}$ & $\begin{array}{l}.315^{* *} \\
(\mathrm{p}=.048)\end{array}$ & $\begin{array}{l}.524^{*} \\
(p=.092)\end{array}$ & $\begin{array}{l}.333^{*} \\
(\mathrm{p}=.051)\end{array}$ & $\begin{array}{l}.317^{*} \\
(\mathrm{p}=.057)\end{array}$ & $\begin{array}{l}.558 \\
(p=.126)\end{array}$ \\
\hline $\begin{array}{l}\text { Years since last } \\
\text { execution }\end{array}$ & -- & & $\begin{array}{l}.023 \\
(p=.116)\end{array}$ & & $\begin{array}{l}.041^{* *} \\
(\mathrm{p}=.036)\end{array}$ \\
\hline $\begin{array}{l}\text { Ethnic } \\
\text { Fractionalization }\end{array}$ & & $\begin{array}{l}-.249 * * * \\
(\mathrm{p}=.000)\end{array}$ & & & $\begin{array}{l}-.271^{* * *} \\
(\mathrm{p}=.002)\end{array}$ \\
\hline $\begin{array}{l}\text { Religious } \\
\text { Fractionalization }\end{array}$ & & & & & $\begin{array}{l}-.843 * * * \\
(\mathrm{p}=.000)\end{array}$ \\
\hline $\begin{array}{l}\text { Language } \\
\text { Fractionalization }\end{array}$ & & & & & $\begin{array}{l}.672 * * * \\
(\mathrm{p}=.000)\end{array}$ \\
\hline $\begin{array}{l}\text { Trade as GDP } \\
\text { share }\end{array}$ & & & & & $\begin{array}{l}.0004 \\
(\mathrm{p}=.078)^{*}\end{array}$ \\
\hline Democracy & & $\begin{array}{l}-. .0005 \\
(p=.616)\end{array}$ & & & $\begin{array}{l}-.002 * \\
(\mathrm{p}=.053)\end{array}$ \\
\hline $\begin{array}{l}\text { Yearly change in } \\
\text { democracy }\end{array}$ & & $\begin{array}{l}-.001 \\
(p=.405)\end{array}$ & & & $\begin{array}{l}-.002 \\
(p=.162)\end{array}$ \\
\hline $\begin{array}{l}\text { Military } \\
\text { government }\end{array}$ & & $\begin{array}{l}.014 \\
(\mathrm{p}=.138)\end{array}$ & & & $\begin{array}{l}.0057 \\
(p=.499)\end{array}$ \\
\hline Federalism & & $\begin{array}{l}.003 \\
(\mathrm{P}=.414)\end{array}$ & & & $\begin{array}{l}.0008 \\
(p=.826)\end{array}$ \\
\hline Left government & & $\begin{array}{l}.017 \\
(\mathrm{P}=.246)\end{array}$ & & & $\begin{array}{l}.022 \\
(p=.215)\end{array}$ \\
\hline Civil war & & & $\begin{array}{l}.005 \\
(p=.675)\end{array}$ & & $\begin{array}{l}.004 \\
(p=.735)\end{array}$ \\
\hline $\begin{array}{l}\text { Civil war } \\
\text { experience }\end{array}$ & & & $\begin{array}{l}-.020 \\
(\mathrm{p}=.157)\end{array}$ & & $\begin{array}{l}-.123^{* * *} \\
(\mathrm{p}=.000)\end{array}$ \\
\hline Interstate war & & & $\begin{array}{l}.003 \\
(p=.702)\end{array}$ & & $\begin{array}{l}.008 \\
(p=.245)\end{array}$ \\
\hline $\begin{array}{l}\text { Logged yrs since } \\
\text { independence }\end{array}$ & & & $\begin{array}{l}.003 \\
(p=.724)\end{array}$ & & $\begin{array}{l}-.011 \\
(p=.691)\end{array}$ \\
\hline $\begin{array}{l}\text { Membership in } \\
\text { Council of } \\
\text { Europe }(\mathrm{t}+3)\end{array}$ & & & & $\begin{array}{l}.0006 \\
(p=.986)\end{array}$ & $\begin{array}{l}.011 \\
(\mathrm{p}=.860)\end{array}$ \\
\hline $\begin{array}{l}\text { Regional death } \\
\text { penalty density } \\
(\mathrm{t}-1)\end{array}$ & & & & $\begin{array}{l}-.066 \\
(p=.548)\end{array}$ & $\begin{array}{l}-.124 \\
(p=.498)\end{array}$ \\
\hline Europe & & & & $\begin{array}{l}.047 \\
(p=.399)\end{array}$ & -- \\
\hline
\end{tabular}




\begin{tabular}{|l|l|l|l|l|l|}
\hline Islam & & & & $\begin{array}{l}.019 \\
(\mathrm{p}=.318)\end{array}$ & $\begin{array}{l}.262^{* * *} \\
(\mathrm{p}=.000)\end{array}$ \\
\hline Log GDP/capita & & & & & $\begin{array}{l}.005 \\
(\mathrm{p}=.788)\end{array}$ \\
\hline Year & & & $\begin{array}{l}-.003 \\
(\mathrm{p}=.120)\end{array}$ & & \\
\hline $\begin{array}{l}\text { Country fixed } \\
\text { effects? }\end{array}$ & yes & yes & yes & yes & yes \\
\hline $\begin{array}{l}\text { Year fixed } \\
\text { effects? }\end{array}$ & yes & yes & yes & yes & yes \\
\hline \# of observations & 5048 & 2695 & 4293 & 4883 & 2298 \\
\hline \# of countries & 165 & 134 & 159 & 164 & 123 \\
\hline $\mathrm{R}^{2}$ & .020 & .084 & .0007 & .003 & .097 \\
\hline
\end{tabular}

$*=$ significant at .10 level $* *=$ significant at .05 level $* * *=$ significant at .01 level 
References:

Albrecht, H.-J. 2000. The Death Penalty in China from a European Perspective. In EuChina Human Rights Dialogue : Proceedings of the Second Eu-China Legal Expert Seminar Held in Beijing on 19 and 20 October 1998, edited by Manfred Nowak and Chunying Xin, 95-118. Wien: Verlag Österreich.

Allain, J., and A. O'Shea. 2002. African Disunity: Comparing Human Rights Law and Practice of North and South African States. Human Rights Quarterly 24(1): 86125.

Ancel, Marc. 1962. The Death Penalty in European Countries. Edited by European Committee on Crime Problems. Strasbourg: Council of Europe.

Asian Human Rights Commission. 2000. Decline of Fair Trial in Asia : Papers from an Asian Seminar on Fair Trial, 7-12 November 1999, Kwoloon, Hong Kong. Hong Kong: Asian Human Rights Commission.

Augusto Cancado, Antonio. 1997. The Right to a Fair Trial under the American Convention on Human Rights. In The Right to Fair Trial in International \& Comparative Perspective, edited by Andrew Byrnes, 4-12. Hong Kong: Centre for Comparative and Public Law University of Hong Kong.

Badawi El-Sheikh, Ibrahim Ali. 1997. Preliminary Remarks on the Right to a Fair Trial under the African Charter on Human and People's Rights. In The Right to a Fair Trial, edited by David S. Weissbrodt and Rüdiger Wolfrum, 327-40. Berlin ; New York: Springer.

Bantekas, Ilias , and Peter Hodgkinson. 2000. Capital Punishment at the United Nations: Recent Developments Criminal Law Forum 11(1): 23-34.

Baumer, Eric P, Steven F Messner, and Richard Rosenfeld. 2003. Explaining Spatial Variation in Support for Capital Punishment: A Multilevel Analysis American Journal of Sociology 108(4): 844-75.

Beccaria, Cesare. 1963. On Crimes and Punishments, The Library of Liberal Arts, 107. Indianapolis,: Bobbs-Merrill.

Beyer, Peter. 2003. Constitutional Privilege and Constituting Pluralism: Religious Freedom in National, Global, and Legal Context. Journal for the Scientific Study of Religion 42(3): 333-39.

Block, Brian P., and John Hostettler. 1997. Hanging in the Balance : A History of the Abolition of Capital Punishment in Britain. Winchester: Waterside Press.

Bodenhamer, David J. 1992. Fair Trial : Rights of the Accused in American History, Bicentennial Essays on the Bill of Rights. New York: Oxford University Press.

Boulanger, Christian, and Austin Sarat. 2005. Putting Culture into the Picture: Toward a Comparative Analysis of State Killing. In The Cultural Lives of Capital Punishment : Comparative Perspectives, edited by Austin Sarat and Christian Boulanger, 1-45. Stanford, Calif.: Stanford University Press.

Bowers, William J., Glenn L. Pierce, John F. McDevitt, and William J. Bowers. 1984. Legal Homicide : Death as Punishment in America, 1864-1982. Boston: Northeastern University Press. 
Brems, Eva. 2006. Article 14 : The Right to Freedom of Thought, Conscience, and Religion, A Commentary on the United Nations Convention on the Rights of the Child,. Leiden ; Boston: Martinus Nijhoff Publishers.

Cameron, Samuel. 1993. The Demand for Capital Punishment. International Review of Law \& Economics 13(1): 47-59.

Council of Europe, European Commission for Democracy through Law, ed. 2000. The Right to a Fair Trial, Collection Science and Technique of Democracy ; No. 28. Strasbourg: Council of Europe Pub.

Danilenko, Gennady M, and William Burnham. 2000. Law and Legal System of the Russian Federation. 2nd ed. [Yonkers, N.Y.]: Juris Pub.

Davis, David Brion. 1957. The Movement to Abolish Capital Punishment in America, 1787-1861. The American Historical Review 63(1): 23-46.

Davis, Derek H. 2002. The Evolution of Religious Freedom as a Universal Human Right: Examining the Role of the 1981 United Nations Declaration on the Elimination of All Forms of Intolerance and of Discrimination Based on Religion or Belief. Brigham You University Law Review: 217-36.

De Neufville, Judith Innes. 1986. Human-Rights Reporting as a Policy Tool - an Examination of the State-Department Country Reports. Human Rights Quarterly 8(4): 681-99.

De Zayas, Alfred M. 1997. The United Nations and the Guarantees of a Fair Trial in the International Covenant on Civil and Political Rights and the Convention against Torture and Other Cruel, Inhuman or Degrading Treatment or Punishment. In The Right to a Fair Trial, edited by David S. Weissbrodt and Rüdiger Wolfrum, 66996. Berlin ; New York: Springer.

De Zayas, Alfred M., Jakob Moller, and Torkel Opsahl. 1985. Application of the Iccpr under the Optional Protocol by the Human Rights Committee. German Yearbook of International Law 28: 9-64.

Donnelly, Jack. 1998. International Human Rights. 2nd ed, Dilemmas in World Politics. Boulder, Colo.: Westview Press.

Dunér, Bertil, and Hanna Geurtsen. 2002. The Death Penalty and War. International Journal of Human Rights 6(4): 1-28.

Durham, W. Cole Jr., and Lauren B Homer. 1998. Russia's 1997 Law on Freedom of Conscience and Religious Associations: An Analytical Appraisal. Emory International Law Review.

Editorial. 1998. Religious Persecution in Today's Germany: Old Habits Renewed. Journal of Church \& State 40(4): 741.

Ehrlich, Isaac. 1975. The Deterrent Effect of Capital Punishment: A Question of Life and Death. The American Economic Review 65(3): 397-417.

Ekirch, A. Roger. 1987. Bound for America : The Transportation of British Convicts to the Colonies, 1718-1775. Oxford: Clarendon Press.

Ellmann, Stephen. 1998. Cause Lawyering in the Third World. In Cause Lawyering : Political Commitments and Professional Responsibilities, edited by Austin Sarat and Stuart A. Scheingold, 349-430. New York: Oxford University Press.

Encyclopædia Britannica. 2007. Human Rights. Encyclopædia Britannica Online.

Evans, Carolyn M. 2002. Chinese Law and the International Protection of Religious Freedom. Journal of Church and State 44: 749-. 
Fawn, Rick. 2001. Death Penalty as Democratization: Is the Council of Europe Hanging Itself? Democratization 8(2): 69 - 96.

Fijalkowski, Agata. 2005. Capital Punishment in Poland: An Aspect of the 'Cultural Life' of Death Penalty Discourse. In The Cultural Lives of Capital Punishment : Comparative Perspectives, edited by Austin Sarat and Christian Boulanger, 14768. Stanford, Calif.: Stanford University Press.

Forsythe, David P. 1985. The United Nations and Human Rights. Political Science Quarterly 100(2): 249-69.

Fox, Jonathan. 2004. The Rise of Religious Nationalism and Conflict: Ethnic Conflict and Revolutionary Wars, 1945-2001. Journal of Peace Research 41(6): 715-31.

Froese, Paul. 2004. After Atheism: An Analysis of Religious Monopolies in the PostCommunist World. Sociology of Religion 65(1): 57-75.

Frymer, Paul. 2003. Acting When Elected Officials Won't: Federal Courts and Civil Rights Enforcement in U.S. Labor Unions, 1935-85. American Political Science Review 97(3): 483-99.

Garland, David. 2001. The Culture of Control : Crime and Social Order in Contemporary Society. Oxford ; New York: Oxford University Press.

Garland, David W. 2002. The Cultural Uses of Capital Punishment. Punishment \& Society 4(4): 459-87.

Gatrell, V. A. C. 1994. The Hanging Tree : Execution and the English People 1770-1868. Oxford [England] ; New York: Oxford University Press.

Ghandhi, P.R. 1986. The Human Rights Committee and the Right of Individual Communication. In British Year Book of International Law, 201-51. Oxford: Clarendon Press.

Hall, John R. 2003. Religion and Violence:Social Processes in Comparative Perspective. In Handbook of the Sociology of Religion, edited by Michele Dillon, xiii, 481. Cambridge, UK ; New York: Cambridge University Press.

Hannum, Hurst. 1991. Contemporary Developments in the Lnternational Protection of the Rights of Minorities. Notre Dame Law Review 66.

Hathaway, Oona. 2002. Do Human Rights Treaties Make a Difference? Yale Law Journal: 101-99.

Heffernan, Liz. 1997. A Comparative View of Individual Petition Procedures under the European Convention on Human Rights and the International Covenant on Civil and Political Rights. Human Rights Quarterly 19(1): 78-112.

Helfer, Laurence R, and Anne-Marie Slaughter. 1997. Toward a Theory of Effective Supranational Adjudication. Yale Law Journal 107(2): 273-391.

Henkin, Louis. 1981. The International Bill of Rights : The Covenant on Civil and Political Rights. New York: Columbia University Press.

-1995. International Law: Politics and Values. Vol. 18, Developments in International Law. Dordrecht: Martinus Nijhoff Publishers.

Ho, Virgil K Y. 2005. What Is Wrong with Capital Punishment? Official and Unofficial Attitudes toward Capital Ppunishment in Modern and Contemporary China. In The Cultural Lives of Capital Punishment : Comparative Perspectives, edited by Austin Sarat and Christian Boulanger, 274-90. Stanford, Calif.: Stanford University Press. 
Hood, Roger. 2001. Capital Punishment: A Global Perspective Punishment \& Society 3(3): 331-54.

Humphrey, John P. 1984. Political and Related Rights. In Human Rights in International Law : Legal and Policy Issues, edited by Theodor Meron, 2 v. (566 ). Oxford [Oxfordshire]: Clarendon Press.

Ishay, Micheline. 2004. The History of Human Rights : From Ancient Times to the Globalization Era. Berkeley: University of California Press.

Jacobs, David, and Jason T Carmichael. 2004. Ideology, Social Threat, and the Death Sentence: Capital Sentences across Time and Space. Social Forces 83(1): 249-78. . 2002. The Political Sociology of the Death Penalty: A Pooled Time-Series Analysis. American Sociological Review 67(1): 109-31.

Jacobs, David, and Ronald Helms. 1997. Testing Coercive Explanations for Order: The Determinants of Law Enforcement Strength over Time. Social Forces 75(4): 1361-92.

Jayawickrama, Nihal. 1997. The Right to a Fair Trial under the International Covenant on Civil and Political Rights. In The Right to Fair Trial in International \& Comparative Perspective, edited by Andrew Byrnes, 37-67. Hong Kong: Centre for Comparative and Public Law University of Hong Kong.

Johnson, David T. 2006. Where the State Kills in Secret: Capital Punishment in Japan. Punishment \& Society 8(3): 251-85.

Keith, Linda Camp. 1999. The United Nations International Covenant on Civil and Political Rights: Does It Make a Difference in Human Rights Behavior? Journal of Peace Research 36(1): 95-118.

Kim, Hunjoon , and Kathryn Sikkink. 2007. Do Human Rights Trials Make a Difference? In Presented at the 2007 Annual Meeting of the American Political Science Association. Chicago.

Koh, Harold H. 1991. Transnational Public Law Litigation. Yale Law Journal 100: 2347.

Kokott, Juliane B. 1997. Fair Trial - the Inter-American System. In The Right to a Fair Trial, edited by David S. Weissbrodt and Rüdiger Wolfrum, 133-62. Berlin ; New York: Springer.

Kolodner, Eric. 1994. Religious Rights in China: A Comparison of International Human Rights Law and Chinese Domestic Legislation. Human Rights Quarterly 16: 45590.

Leigh, Leonard H. 1997. The Right to a Fair Trial and the European Convention on Human Rights. In The Right to a Fair Trial, edited by David S. Weissbrodt and Rüdiger Wolfrum, 645-68. Berlin ; New York: Springer.

Lerner, Natan. 2000. Religion, Beliefs, and International Human Rights, Religion and Human Rights Series. Maryknoll, N.Y.: Orbis Books.

- 2006. Religion, Secular Beliefs, and Human Rights : 25 Years after the 1981 Declaration, Studies in Religion, Secular Beliefs, and Human Rights, V. 2. Leiden ; Boston: Martinus Nijhoff Publishers.

- 1996. Religious Human Rights under the United Nations. In Religious Human Rights in Global Perspective : Legal Perspectives, edited by J. D. Van der Vyver and John Witte, 79-134. The Hague: M. Nijhoff Publishers. 
Lillich, Richard B. 1984. Civil Rights. In Human Rights in International Law : Legal and Policy Issues, edited by Theodor Meron, 2 v. (566 ). Oxford [Oxfordshire]: Clarendon Press.

Linebaugh, Peter. 1991. The London Hanged : Crime and Civil Society in the 18th Century. London: Allen Lane : The Penguin Press.

Little, David. 1996. Studying 'Religious Human Rights': Methodological Foundations. In Religious Human Rights in Global Perspective : Legal Perspectives, edited by J. D. Van der Vyver and John Witte, 45-77. The Hague: M. Nijhoff Publishers.

Livezey, Lowell W. 1989. Us Religious Organizations and the International Human Rights Movement. Human Rights Quarterly 11(1): 14-81.

Martin, William. 1999. The Christian Right and American Foreign Policy. Foreign Policy(114): 66-80.

Matscher, Franz. 2000. The Right to a Fair Trial in the Case-Law of the Organs of the European Convention on Human Rights. In The Right to a Fair Trial, edited by European Commission for Democracy through Law Council of Europe, 10-23. Strasbourg: Council of Europe Pub.

McGoldrick, Dominic. 1991. The Human Rights Committee. Oxford: Clarendon Press.

Merry, Sally Engle. 2006. Human Rights and Gender Violence : Translating International Law into Local Justice, Chicago Series in Law and Society. Chicago: University of Chicago Press.

Miethe, Terance D., Hong Lu, and Gini R. Deibert. 2005. Cross-National Variability in Capital Punishment: Exploring the Sociopolitical Sources of Its Differential Legal Status. International Criminal Justice Review 15(2): 115-30.

Mohamad, Maznah. 2002. Towards a Human Rights Regime in Southeast Asia: Charting the Course of State Commitment. Contemporary Southeast Asia: A Journal of International \& Strategic Affairs 24(2): 230.

Myullerson, Rein. 1992. Monitoring Compliance with International Human Rights Standards: Experience of the Un Human Rights Committee. In Canadian Human Rights Yearbook, 1991-1992, 105-18. Ottawa: University of Ottawa Human Rights Research and Education Centre.

North, Charles M., and Carl R. Gwin. 2004. Religious Freedom and the Unintended Consequences of State Religion. Southern Economic Journal 71(1): 103-17.

Odio Benito, Elizabeth. 1989. Elimination of All Forms of Intolerance and Discrimination Based on Religion or Belief. Edited by United Nations Centre for Human Rights., Human Rights Study Series, 2. New York: United Nations.

Ohlin, Jens David 2005. Applying the Death Penalty to Crimes of Genocide. The American Journal of International Law 99(4): 747-77.

Osofsky, H. M. 1997. Domesticating International Criminal Law: Bringing Human Rights Violators to Justice. Yale Law Journal 107(1): 191-226.

Otterbein, Keith F. 1986. The Ultimate Coercive Sanction : A Cross-Cultural Study of Capital Punishment. New Haven, Conn.: HRAF Press.

Palmer, John P., and John Henderson. 1998. The Economics of Cruel and Unusual Punishment European Journal of Law and Economics 5(3): 235-45.

Partsch, Karl Josef. 1981. Freedom of Conscience and Expression, and Political Freedoms. In The International Bill of Rights : The Covenant on Civil and 
Political Rights, edited by Louis Henkin, x, 523. New York: Columbia University Press.

Perry, Michael J. 2007. Toward a Theory of Human Rights : Religion, Law, Courts. Cambridge ; New York: Cambridge University Press.

Potter, Harry. 1993. Hanging in Judgment : Religion and the Death Penalty in England. New York: Continuum.

Potter, Pitman B. 2003. Belief in Control: Regulation of Religion in China. The China Quarterly 174: 317-37.

Puhar, Eva. 2005. The Abolition of the Death Penalty in Central and Eastern Europe: A Survey of Abolition Processes in Former Communist Countries. In Occasional Papers Series Vol. II. Centre for Capital Punishment Studies: University of Westminster.

Radzinowicz, Leon. 1999. Adventures in Criminology. London ; New York: Routledge. Ribeiro. 1987. Implementation of the Declaration on the Elimination of All Forms of Intolerance and of Discrimination Based on Religion or Belief. edited by United Nations.

Riis, Ole. 1999. Modes of Religious Pluralism under Conditions of Globalisation. International Journal on Multicultural Societies 1(1): 20-34.

Roan, Michael. 1996. The Role of Secular Non-Governmental Organizations in the Cultivation and Understanding of Religious Human Rights. In Religious Human Rights in Global Perspective : Legal Perspectives, edited by J. D. Van der Vyver and John Witte, 135-59. The Hague: M. Nijhoff Publishers.

Ruddell, Rick. 2005. Social Disruption, State Formation and Minority Threat: A Crossnational Study of Imprisonment. Punishment \& Society 7(7-28).

Ruddell, Rick, and Martin G. Urbana. 2004. Minority Threat and Punishment: A CrossNational Analysis. Justice Quarterly 21(4): 903-31.

Sangroula, Yubaraj. 2000. Fair Trial: Still a Long Way to Achieve in Nepal. In Decline of Fair Trial in Asia : Papers from an Asian Seminar on Fair Trial, 7-12 November 1999, Kwoloon, Hong Kong, edited by Asian Human Rights Commission. and Danske menneskerettighedscenter., 195-215. Hong Kong: Asian Human Rights Commission.

Schabas, William. 2002. The Abolition of the Death Penalty in International Law. 3rd ed. Cambridge, UK ; New York, NY, USA: Cambridge University Press.

Shapiro, Steven R. 1993. Human Rights Violations in the United States : A Report on U.S. Compliance with the International Covenant on Civil and Political Rights. Edited by Human Rights Watch (Organization) and American Civil Liberties Union. New York: Human Rights Watch : American Civil Liberties Union.

Sharif, Adel Omar. 2000. The Rule of Law in Egypt from a Judicial Perspective : A Digest of the Landmark Decisions of the Supreme Constitutional Court. In The Rule of Law in the Middle East and the Islamic World : Human Rights and the Judicial Process, edited by Eugene Cotran and Mai Yamani, 1-34. London: I.B. Tauris.

Sieghart, Paul. 1983. The International Law of Human Rights. Oxford: Clarendon Press. Sigmund, Paul E. 1996. Religious Human Rights in Latin America. In Religious Human Rights in Global Perspective : Legal Perspectives, edited by J. D. Van der Vyver and John Witte, 467-81. The Hague: M. Nijhoff Publishers. 
Simmons, Beth A. forthcoming. International Human Rights: Law Politics and Accountability. New York: Cambridge University Press.

Skeen, Andrew. 2000. The Right to a Fair Trial in South African Law. In The Right to a Fair Trial, edited by European Commission for Democracy through Law Council of Europe, 110-29. Strasbourg: Council of Europe Pub.

Soss, Joe, Laura Langbein, and Alan R. Metelko. 2003. Why Do White Americans Support the Death Penalty? The Journal of Politics 65(2): 397-421.

Sullivan, Donna J. 1988. Advancing the Freedom of Religion or Belief through the Un Declaration on the Elimination of Religious Intolerance and Discrimination. The American Journal of International Law 82(3): 487-520.

Sung, Hung-En 2006. Democracy and Criminal Justice in Cross-National Perspective: From Crime Control to Due Process. The ANNALS of the American Academy of Political and Social Science 605(1): 311 - 37.

Sutton, John R. 2000. Imprisonment and Social Classification in Five Common-Law Democracies, 1955-1985. American Journal of Sociology 106(2): 350-86.

Swinarski, Christophe. 1997. On the Right to a Fair Trial under International Humanitarian Instruments. In The Right to Fair Trial in International \& Comparative Perspective, edited by Andrew Byrnes, 26-36. Hong Kong: Centre for Comparative and Public Law University of Hong Kong.

Tahzib, Bahiyyih G. 1996. Freedom of Religion or Belief : Ensuring Effective International Legal Protection, International Studies in Human Rights ; V. 44. The Hague: M. Nijhoff.

Talbi, Mohamed. 1986. Religious Liberty: Amuslim Perspective. In Religious Liberty and Human Rights in Nations and in Religions, edited by Leonard J Swidler, 17587. Philadelphia: Ecumenical Press.

Taylor, Paul M. 2005. Freedom of Religion : Un and European Human Rights Law and Practice. Cambridge, UK ; New York: Cambridge University Press.

Tolley, Howard. 1991. Interest Group Litigation to Enforce Human-Rights. Political Science Quarterly 105(4): 617-38.

Tshosa, Onkemetse. 2001. National Law and International Human Rights Law : Cases of Botswana, Namibia and Zimbabwe, Law, Social Change, and Development Series. Aldershot ; Burlington, USA: Ashgate.

Turrell, Robert Vicat. 2004. White Mercy : A Study of the Death Penalty in South Africa. Westport, Conn.: Praeger.

van Dijk, Pieter. 1983. The Right of the Accused to a Fair Trial under International Law. Edited by Studie- en Informatiecentrum Mensenrechten (Netherlands), Sim Special ; No. 1. Utrecht, The Netherlands: Studie- en Informatiecentrum Mensenrechten.

Weissbrodt, David, and Mattias Hallendorff. 1999. Travaux Preparatoires of the Fair Trial Provisions - Articles 8 to 11 - of the Universal Declaration of Human Rights. Human Rights Quarterly 21(4): 1061-96.

Weissbrodt, David S. 2001. The Right to a Fair Trial under the Universal Declaration of Human Rights and the International Covenant on Civil and Political Rights, Universal Declaration of Human Rights ; 1 . The Hague: M. Nijhoff.

Whitman, James Q. 2003. Harsh Justice : Criminal Punishment and the Widening Divide between America and Europe. Oxford ; New York: Oxford University Press. 
Wolpin, Kenneth I. 1978. Capital Punishment and Homicide in England: A Summary of Results. The American Economic Review 68(2): 422-27.

Wyman, James H. 1997. Vengeance Is Whose?: The Death Penalty and Cultural Relativism in International Law. Journal of Transnational Law \& Policy 6(2): 543-70.

Wynarczyk, Peter. 1999. The Political Economy of Capital Punishment. Economic Affairs 19(1): 43-47.

Zimring, Franklin E. 2003. The Contradictions of American Capital Punishment, Studies in Crime and Public Policy. Oxford ; New York: Oxford University Press. 